\title{
VADJA ASUSTUSNIMED
}

\author{
ENN ERNITS
}

Annotatsioon. Kirjutises vaadeldakse vadja asustusnimesid, keskendudes vadjalastega asustatud, samuti neile tuntud teiste Vadjamaa külade nimedele. Külanimed on liigitatud semantiliste rühmade kaupa tähestikulises järjestuses. Igale nimele on lisatud huvipakkuvad varasemad kirjapanekud alates 1500. aastast ja XX sajandil talletatud murdevariandid. Vadjamaa nimesid, mida on peale vadjalaste andnud ka teised Ingerimaa rahvad, on senisest ulatuslikumalt kõrvutatud eesti ja soome toponüümidega. Uuritud on ka vadja ja naaberkülade venekeelseid nimesid ning nende suhteid vadja nimedega. Samuti on uurimise all Ingerimaa ja Eestiga seotud linnanimed ning ajaloolised mõisanimed, lisaks antakse ülevaade nii talunimedest kui ka mitmesuguste rajatiste nimedest.

Võtmesõnad: asustusnimed, etümoloogia, vadja keel, isuri keel, vene keel, Vadjamaa, Ingerimaa, Eesti

\section{Sissejuhatus}

Kirjutises käsitletakse asustusnimesid avaramalt kui tavaliselt, mispuhul need hõlmavad mitte üksnes asulate (linnad, külad) ja nende alaosade (linna- ja külaosad) nimesid, vaid kõiki objekte, mis on seotud maa-ala rahvastiku ja asulastikuga taludest kuni riikideni, samuti on kaasatud väiksemaid tehisobjekte, nagu hooned, teed.

Vadja toponüümiat on 1960. aastatel uurinud fennougrist ja votoloog Paul Ariste (1905-1990). Tema „Baabino ehk Jarvigoiščülä“ (1964) ja „Vadja kohanimedest“ (1965a) on põhjalikud kirjutised, millest ühes käsitletakse külanime Jarvigoiščülä, teises aga vadja-täiendosa Eesti ja Ingerimaa kohanimedes. Oma järgmistes kirjutistes on Ariste võtnud vaatluse alla igat tüüpi kohanimed (Ariste 1965b, 1967, 1968, kusjuures kaks viimast artiklit on sisult ja sõnastuselt identsed). Need annavad vadja toponüümiast sisuka ülevaate, kuid konkreetseid nimerühmi ja nimesid on käsitletud üpris põgusalt. Teistest põhjalikumalt on Ariste uurinud 
piirkonna- ja asulanimesid. Külanimesid on ta vaadelnud objektirühmade kaupa, pöörates enim tähelepanu neis sisalduvatele liidetele.

Käesoleval sajandil on vadja toponüüme uurinud Leningradi oblasti Kingissepa rajooni asjaarmastajad, kelle tulemused on paraku enamasti meelevaldsed (TKR). Selle peamised põhjused on toponüümia uurimise meetodite ja teiste teadlaste tulemuste eiramine ning läänemeresoome keelte mittetundmine. Vadja alasid puudutavad Kattila kodu-uurija Tamara Barabaši ja Jõgõperä keskkooli õpilase A. K. Baranovi pealkirjata lühikirjutised. Asjalikud on asustusnimede ajalugu pikka aega uurinud Peterburi Polütehnilise Ülikooli dotsendi Aleksandr Dmitrijevi artiklid, mis toetuvad ürikuainesele (nt Dmitrijev 2007).

Esimesed vadja alade kohanimed on kirjasõnasse sattunud juba kolmveerand tuhande aasta eest. Esimene neist on ladinakeelne Vadjamaa nimetus omastavalisel kujul 1230 Watlandie ja 1240 Watlande (vt Dmitrijev 2018: 273 jj). Olulised toponüümide allikad on Moskva vürstiriigi XVI sajandi maksukatastrid (vn писцовые книги) ja järgnenud aastasaja maaraamatud (rts Jordeböcker), samuti igasugused maakaardid Rootsi ajast alates.

Süstemaatiliselt hakati vadja toponüüme koguma alles XX sajandi teisel poolel. Sellest annab tunnistust kaks kogu, mida säilitatakse Tallinnas Eesti Keele Instituudi kohanimekartoteegis. Esimene neist (639 nimesedelit) on Eesti Keele Instituudi anonüümne, tõenäoliselt 1960. aastatest pärinev kogu, mis sisaldab ainest kõigilt murdealadelt, sh kirjanduses avaldatud vadja tekstidest nopitud toponüüme; nende ebatäpsust sedelitel on pärastpoole agaralt mitmeti korrigeeritud. Teine on sealsamas säilitatav Emakeele Seltsi kogu, mille 317 sedelit on talletanud A. Lõhmus 1972. aasta suvel Mati külast ja kogu Vaipoolest.

Ühel või teisel määral sisaldavad toponüümiat ka Ilmar Talve 1981. aasta teos ja vadja sõnaraamatud (Posti 1980; Kettunen 1986; Tsvetkov 1995; VKS). Kõige rikkalikum on kohanimede poolest Lauri Posti koostatud Kukkuzi murde sõnaraamat (1980). Rohkesti toponüüme sisaldab Ariste 18 mapist koosnev käsikirjaline kogu ,Vadja etnoloogiat“ (VE). Üksikuid kohanimesid võib leida publitseeritud vadja tekstidest ja ilmselt mujaltki.

Siinses kirjutises kasutatakse kõiki eespool mainitud allikaliike, v.a hilisemaid publitseeritud vadja tekste, kus leidub, tõsi küll, vaid üksikuid toponüüme. Vadja kohanimede uurimisel kasutatakse läbivalt VKSi 
koondatud üldsõnavara, isurite näidete allikas on isuri keele sõnaraamat (Nirvi 1971). Vadjamaa kohanimede võrdlemisel läänemeresoomeliste naaberalade omadega on tuginetud põhiliselt EKNRile, KKle ja SPKle. Vadja asustusnimede lokaliseerimisel võiks lugeja huvi korral ette võtta vadja kohanimede kaardi (vt VKS: 94).

Enamik toponüüme on külanime lühendiga, millele on ruumi kokkuhoiu mõttes allikas lisatud indeksina (vt lühendid). Külanime lühend osutab keelejuhi elukohaks olevale külale (= murrakule). Sulgudes esitatud lühend näitab, et kohanimi pole algsel kujul talletatud nominatiivis, st põhikäändes kuju on kohanimesedeli koostaja tuletatud. Teadmata külanime märgib X. Tärn * tänapäeva vadja üldsõna ees viitab lekseemi puudumisele VKSis, mujal tähistab see rekonstrueeritud sõnakujusid. Kirjasõnast sedeldatud kohanimedel on Eesti Keele Instituudi kartoteegikaartidel lisatud viide algallikale (autor, ilmumisaasta, lehekülg); praegusel juhul piirdutakse vaid autorinimega, mis järgneb külanimele sidekriipsu abil. Vajaduse korral võib huviline lähemaid andmeid leida kohanimekartoteegist. Siinkirjutaja täiendused on paigutatud nurksulgudesse.

Vadja toponüümide kirjapilti on ühtlustatud ja lähendatud kirjakeelele, kusjuures on tehtud järgmised muudatused: $c \rightarrow t s, c c \rightarrow t t s, t \check{s} \rightarrow \check{c}$, $t t \check{s} \rightarrow \check{c} \check{c}$. Kattila ja Kabrio murde nõrgas astmes geminaat jääb tähistamata.

Artiklis püütakse anda vadja asustusnimedest terviklik ülevaade. ${ }^{1}$ Peatähelepanu on pööratud kohanimede päritolule. See võimaldab paigutada kohanimed atribuutide ehk täiendosade järgi tähendusrühmadesse. Seejuures on Vadjamaa mitmekeelses olustikus sageli võimatu määrata kohanimede keelelist kuuluvust. Öeldu kehtib võimalike isuri ja ingerisoome nimede kohta, kuid ei puuduta vene laene. Põhjalikumalt on vaadeldud vadjalastele tuntud Ingerimaa linnade ja eriti vadjalastega asustatud külade nimesid. Tähelepanu on pälvinud vadjalastele teada olnud Eesti ala toponüümia, samuti Vadjamaa mõisate, talude, rajatiste jm nimed. Kõrvale on jäänud piiblist ja muust kirjasõnast loetud ning meremeestele tuntud lähedaste ja kaugete kohaobjektide nimed. Esimest korda on ulatuslikumalt arvesse võetud varasemaid kirjapanekuid, samuti võrreldakse omavahel vadja- ja venekeelseid nimesid. Käsitlust alustatakse maa- ja piirkonnanimedega ning see lõpetatakse üksikrajatiste omadega; ülejäänud asustusnimed jäävad nende vahele.

Siinkirjutaja on väga tänulik mõlemale retsensendile rohkete kasulike paranduste ja täienduste eest. 


\section{Maa- ja piirkonnanimed}

Alljärgnevad toponüümid, kui pole märgitud teisiti, pärinevad Eesti Keele Instituudi kohanimekogust. Maade nimedest mainitagu siinkohal huvipakkuvatena vaid Lu Eestii maa 'Eestimaa', J (Lu) Soomi 'Soome' (VKS), Lu (M) Venamaa, $\mathrm{Ku}^{\mathrm{P}}$ Vennäämaa, ${ }^{\mathrm{Ts}}$ Venäi $\sim$ Venäi-maa, $\mathrm{Ma}^{\mathrm{K}}$ Venää maa 'Venemaa' (VKS) ja ${ }^{\mathrm{Ts}} \mathrm{Ku}^{\mathrm{P}}$ Viro 'Eesti'. Ven-tüve paralleelsed ees- ja tagavokaalsed toponüümivariandid ning üldsõnad esinevad samades murrakutes (M Lu venaa vennää 'vene', Lu vennai vennäi 'vene', $\mathrm{K}$ venakko 'venelanna', $\mathrm{M}$ venalain venäläin 'venelane').

Vadjalased eristasid oma asualal ja naabruses mitut piirkonda, nagu Maa Maa-pooli Maa-selčä 'Maaselg', Orko 'Org', mille alla külade paigutamine on olnud mõneti varieeruv (vt lähemalt Ariste 1967: 77-78; Talve 1981: 1.1-1.6). Piirkonnanimede hulka kuuluvad Lu Laukaapool 'Lauga jõe äärne kant' < Laugaz : Laukaa + pool pooli 'pool, kant' ja Lu Perskunta 'Ühismäe ehk Krasnogorka ümbrus Koporje lähedal' $<$ pers perse 'tagumik' + kunta '-kond, ala, piirkond'. Andmeid on vaid paari administratiivüksuse nime kohta: M Ičäpäivää valta, M Kattiloizvalta (mõlemad VE II: 35) ja J Jaamaa ujezd 'Jamburgi maakond' (ujezd $<$ vn).

\section{Linnanimed}

Linnade (vdj lidna) nimedest käsitletakse artiklis vadjalastega rohkem seotud Ingerimaa linnade nimesid, aga ka vadjalastele tuntud Eesti linnade omi. Erandiks on siinkohal vaid $\mathrm{J} \mathrm{Ku}{ }^{\mathrm{P}}$ Uuzlinna $\sim$ Uuslinna 'Novgorod' $<$ uиsi 'uus' + linna 'linn', seega otsetõlge vene keelest (vrd vn новый 'uus' + город 'linn'). Kõik linnanimed pärinevad Eesti Keele Instituudi murdekogust, seepärast jäävad nad tähiseta.

\subsection{Ingerimaa linnade nimed}

Vadjalastel olid kasutusel omakeelsed nimed Jaanilinna, JamburgiKingissepa, Koporje, Kroonlinna, Oranienbaumi-Lomonossovi ja Peterburi kohta. Nende käsitlemisel esitatakse kõigepealt poolpaksus kirjas vadja toponüümi põhikuju, millele järgnevad ajaloolised ja praegused venekeelsed nimed. 
Ivoolidna (vvn Иванградъ, vn Ивангород). Jaanilinna nimi on moodustatud mitut moodi, kuid ühisosaks on enamasti vene isikunimi Ivan ja selle vadja vaste Ivo. Kindlus sai nime selle asutaja Moskva suurvürsti Ivan III järgi. Vadja linnanime kujud on J Iivõni-mäči; Lu Ivana-mäči < mäči 'mägi'; (Ku)-Kettunen-Posti Ivanosko; J Ivanovski; Lu Ivoolidna, Lu Ivoolidna (VE XII: 17), Ivvoo lidna (Ariste 1967: 79), vrd lidna 'linn'. Linnus rajati leetopissi järgi Neiumäele (vn Девичья гора на слуде '[Narva] kaldajärsakul'), millega seostub ehk nimeosis mäči, teisalt võis nime mõjustada ka sõnade гора 'mägi' ja город 'linn' mõnetine sarnasus. Ivanovski on kujunenud venekeelsest sõnaühendist Ивановский форштадm 'Ivani eeslinn', sest kindluse ümber tekkinud asula oli 1945. aastani Narva eeslinnu (IEO; EKNR: Jaanilinn). Ivanosko tuleneb tõenäoliselt vormist *Ivanovsko, kuid otsene vene eeskuju jäi leidmata.

Jaama (alates 1703 Ямбург, aastast 1922 Кингисепn). Jamburgi kindluse ja linna (1384 Яма; 1397 Ямской городок, hiljem Ям) vadja nimekujud on I Ja (Ku) ${ }^{\mathrm{P}}(\mathrm{Kõ}) \mathrm{Lu}$ M P S (V) Jaama; M Jaamalidna Jaamaa lidna; Lu Jaama-lidna; J J ${ }^{\mathrm{Ts}} \mathrm{Lu}$ Jaamõ; $v$ rd is $^{\mathrm{N}}$ Jaama. Põhisõna päritolu pole selge. Seda on ühendatud vene apellatiividega яма 'auk', ям 'postijaam' jt. Igatahes näib Vladimir Nikonovi (1966: 191) mainitud seos vanavene sõnaga я.мb 'hämelane' olevat ebausutav. Vadjalased on kasutanud ka uuema aja linnanime Kingiseppä, mille omaksvõttu on toetanud selle läänemeresoome päritolu (Ariste 1967: 83).

Kabrio (vn Konopbe). Koporje küla, kindluse ja linna vadjapärased nimekujud on J Ku Li Lu Kabrio, J Lu Kabro, vrd is ${ }^{\mathrm{N}}$ Kabrio. Toponüüm tuleneb läänemeresoome päritolu sõnast *kabri 'metskits'; arvatavasti oli tegu kitserohke paigaga (Ariste 1967: 83). Soome keeleteadlane Lauri Kettunen on esitanud vadja toponüümi kõrvutuseks ee Kaberla ja sm Kauriala ning seostanud neid üldsõnadega sm kauris 'kaljukits', vps kabroi ja lv kabriki (EO: 72; vt ka EKNR: Kaberla ja Kaberneeme). Koduloolase Aleksandr Vorontsovi oletus linnanime seosest soome sõnaga korpi 'laas, põlismets' ja vene keeleteadlase Vladimir Neroznaki kõrvutus vanavene sõnaga коnатu 'kaevama' on aluseta (TKR: 54; Neroznak 1983: 92-93).

Vadja nimest on kujunenud vene nimi Koporje (Konopbe), millel põhinevad sekundaarselt vadja ülejäänud rohked nimemoodustised, nagu P Kaapoŕo, M Kaapoŕoo čülä, Ja-Lensu Kaporja, Ja-Lensu Kaporja lidna, Kõ-Lensu Kaporjo, I Kapoŕjo, J M P Kapoŕo ja Lu Koporje 'Koporje küla ja linn'. 
Petteri (vn Санкт-Петербург). Ingerimaa, pärastise Peterburi kubermangu ja Vene impeeriumi kunagise pealinna Sankt-Peterburgi, samuti hilisema Leningradi nimi oli vadjalastel ja ka isuritel I J K (Ku) (Kõ) Li Lu M Ma ${ }^{\mathrm{K}} \mathrm{P}$ (R) S (U) Petteri, ühel juhul Ja-Lensu Petterilidn $a$, vrd ka is ${ }^{\mathrm{N}}$ Petteri. Kohanime aluseks on ametlik saksapärane vene nimi. Vähem on kasutatud soome keelest laenatud nime K P (R) Pietäri, Lu Pietärii.

Rambov (vn Ораниенбаум, alates 1948 Ломоносов). Praeguse Lomonossovi varasem nimi Oranienbaum pärineb saksakeelsest sõnast tähendusega 'apelsinipuu'; selle lähteks on omakorda prantsuse orange 'apelsin'. Nimi seostub tõigaga, et XVIII sajandil kasvatati Peeter I aegse sõjaväelase ja riigimehe Aleksandr Menšikovi lossi kasvuhoonetes apelsine. Kohalik elanikkond lihtsustas toponüümi juba XVIII sajandil, mispuhul see omandas kuju Rambov (vn Рамбов), mida kasutatakse vene keeles tänini ajalehtedes, siltidel jm (OPP). Sama nimelühend tuli kasutusele ka vadja keeles, kuid see muudeti vokaallõpuliseks: M Rambova, M Rambovaa lidna, J Li Lu Rambovi. Vaipooles on sama linna kohta tarvitatud ka nime J Lu Kaarosta, mis tuleneb seda läbiva jõe nimest (vn Kapacma). Viimase algupära pole siinkirjutajale teada. Sama nimekuju oli tuntud ka isuritele, nagu selgub rahvalauludest, nt tiimmä linnan liivikolle, / Kaarassan kylän kaulle 'teeme linna liivikule, Kaarasta küla tänavale(?)' (NPI: 118). Pole võimatu, et vadja nimi ongi laenatud isuritelt või isegi ingerisoomlastelt.

Saari (vn Кронштадт). Kroonlinn paikneb suhteliselt suurel Kotlini saarel, seepärast on linna nimekujudeks saanud X Saari (Ariste 1967: 79) ja Ma ${ }^{\mathrm{K}}$ Saarõ (vrd is ${ }^{\mathrm{N}}$ Saari; vdj, is saari 'saar'). Vadjalased on kasutanud ka saksapärast vene nime (Lu) Kronštatti (VE XXII: 29).

\subsection{Eesti linnade nimed}

Vadjalased on paremini tundnud Põhja-Eestit, sh rohkem Vadjamaale lähemal asuvaid linnu. Lõuna-Eestist pärineb ainult Tartu ja Valga nimi.

Jõhvi. Vadjalased on kasutanud nimekuju J Jevi-lidna, mille eeskujuks on olnud üldsõna jevi 'jõhv'.

Narva. See oli vadjalaste jaoks lähim Eesti ala linn. Selle nimest on registreeritud järgmised teisendid: J V Naarva, J Js Narv, I J ${ }^{\mathrm{Ts}} \mathrm{K}$ Ku $(\mathrm{Ku})^{\mathrm{P}}(\mathrm{Kõ}) \mathrm{L}$ Li Lu M Ra S (V) Narva, Ra Narvaa linna. Esisilbi vokaali 
pikenemine on johtunud vene keele ehk rõhulise silbi mõjust. Narva linnaosadest on registreeritud J Petrovski 'Peetri eeslinn' < vn; Pesälidna < *pesälidna 'kesklinn' < pesä 'pesa' + lidna 'linn'.

Narva-Jõesuu. Selle kohta on vadjalased kasutanud nelja nime: Lu Jõgõsuu < jõki : jõgõõ 'jõgi : jõe'; Lu Meresuu (VE IX: 70); X Meree suu (Ariste 1967: 79) < meri; J J ${ }^{\mathrm{Ts}}(\mathrm{Ku})^{\mathrm{P}} \mathrm{Lu}(\mathrm{Ra})$ Pakari (ka Ra Pakarii meri 'Narva laht') ja (Lu) Ust'-Naroova (VE XII: 267). Viimane pärineb vene keelest. Jõgõõsuu ja mere-suu on ka üldsõnadena sünonüümid: Lu meresuu on se, kuhõõ jõki lopub, vai jõgõõsuu 'meresuu või jõesuu on see, kuhu jõgi lõpeb' (VKS). Kuidas on tekkinud aga Pakari? Kas Narva-Jõesuu kant on muiste kandnud seda nime või on see mingil põhjusel Narva-Jõesuule siirdunud Jõhvi kihelkonna Pagari külalt (hiljem mõis)? Ee Pagari päritolu on jäänud hämaraks (vt EKNR). Üks võimalus on kõrvutada asjaomaseid kohanimesid soome perekonnanimedega Pakarainen ja Pakarinen. ${ }^{2}$ Nime Pakarinen esinemise kohta on teateid alates XV sajandi algusest (nt 1413 Laurens Pakarinpoika); nime seostatakse rootsi laensõnaga pakari paakari 'pagar'. Meie Pagarit on mainitud 1241. aastal kujul Paccari, 1550 Pagger. Uuritavaid kohanimesid saab ühendada pagarit tähistava apellatiiviga, kui arvestada seni oletatust varasemat laenamisaega ja senisest erinevat laenuallikat. ${ }^{3}$

Rakvere. Linnanimi esineb vadja keeles mitmel kujul: M Rakaveeri, X Rakkaveeri (Ariste 1967: 79), $\mathrm{Ku}^{\mathrm{P}}$ Rakkavoori, (Li) Rakkoveeri (VE XV: 63), (J) Lu Rakkveere, Li Lu Rakkveeri, Js Rakkvere, J Rakkvoori, $\mathrm{J}^{\mathrm{Ts}}$ Rakvere 'Rakvere'. Seegi toponüüm on mitmeti huvitav, sest mõnda varianti iseloomustavad 1) sisekao puudumine, 2) vastavus ee -vere vdj -veeri 'veer, äär; pool' ja 3 ) järelosis -voori (< ?*voori). Nimekujud meenutavad XIII sajandi vanavene leetopissis kajastuvat nime Раковоръ

2 Pakarainen võib ehk tuleneda üldsõnast pakara 'tuhar; tagumik'. Sama sõna eksisteerib ka vadja ja isuri keeles, kuid lõpuvokaali erinevuse tõttu ei sobi see kohanime kõrvutusaineks.

3 Kettunen ei seostanud kohanime Pagari apellatiiviga pagar sõnade erineva vanuse pärast (EO: 182). Ariste (1936: 196) pidas eesti sõna pagar Rootsi ajast, st XVI-XVIII sajandist pärinevaks laenuks. Soome perekonnanime esmamainingut (üldsõnana talletatud alles 1609) ja eesti toponüümi varaseimat kuju silmas pidades võiks arvata, et asjaomane Põhja-Eesti sõna oli tuntud siiski juba oluliselt varem. Sel juhul sobiks laenuallikaks vanataani (1100-1500) bakcer, vrd taani bager (DEO: 16; SSA II: 278). 
ja XVIII sajandi soome sõnaraamatus leiduvat Rahcavuori ning võivad ehk kaasa aidata eesti nime päritolu täpsemale selgitamisele (vt EKNR: Rakvere; Ernits 2017: 195-196).

Tallinn ja Tartu. Eesti pealinna nimi on pandud kirja kahel kujul: $\mathrm{J} \mathrm{J} \mathrm{Js}^{\mathrm{Ts}} \mathrm{Ku}^{\mathrm{P}} \mathrm{Kõ} \mathrm{Lu} \mathrm{Reeveli,} \mathrm{J} \mathrm{Rieveli,} \mathrm{Lu} \mathrm{Reveli} \mathrm{ja} \mathrm{Lu} \mathrm{Talina} \sim$ Tallina. Esimene neist pärineb tsaariaegsest venekeelsest Tallinna nimest Ревель. Tartu nimest on kasutatud nii $o$ - kui ka $u$-lõpulist kuju: J J ${ }^{\mathrm{Ts}} \mathrm{Ku}(\mathrm{V}) \mathrm{Tarttu}$, Lu Tartto.

Valga ja Viljandi. Vadja nimekujud $\mathrm{J}^{\mathrm{Ts}} \mathrm{X}$ Valkk 'Valga' ja $\mathrm{J}^{\mathrm{Ts}}$ Fellin lähtuvad venekeelsetest nimekujudest (vastavalt Валк ја Феллин), mis on omakorda võetud üle saksa keelest (vrd Walk, Fellin). Lõppkokkuvõttes lähtuvad mõlemad linnanimed eesti keelest (lähemalt vt EKNR: Valga ja Viljandi).

\section{Mõisad}

Vadjamaal ja selle naaberaladel asus rohkesti mõisaid (vdj mõiza). Kõiki mõisanimesid pole paraku kirja pandud. Näiteks pole nimetatud Aleksandrovka ehk Kopanetsi mõisat Kopanitsõ külas, Bereznjaki mõisat Kazikko külas, Valgovitsõ mõisat samanimelises külas, Georgijevskaja ehk Petrovskaja mõisat Pihlaala (vn Пиллово) lähedal (DUS: 234-236). Mõnd mõisanime on praegustel andmetel võimatu lokaliseerida. Mõisate nimed tulenevad enamasti külade nimedest, harvem omaniku nimest.

Küla järgi on nimetatud $\mathrm{M}^{\mathrm{ES}}$ Ičäpäivää mõiza, $\mathrm{I}^{\mathrm{EK}} \mathrm{J}^{\mathrm{EK}} \mathrm{K}^{\mathrm{EK}} \mathrm{M}^{\mathrm{EK}}$ Ičäpäivä, (I) Ičäpäivää moiśo (VE I: 237), (M) Ičäpäivää mõiza (VE XII: 211); M Kattilaa mõiza (VE IX: 147), Lu ${ }^{\mathrm{ES}}$ Kattilaa mõiza, (M) Kattiloizmõiza (VE XV: 129); Lu ${ }^{\mathrm{ES}}$ Kõhčizõõ mõiza 'mõis Kõhtsõ külas' (vn Косколова; DUS: 235); Li ${ }^{\mathrm{ES}}$ Narvuzii mõiza 'mõis Narvuzi lähedal' (vn Галики Куземкино; DUS: 199 jj); Ku Ńeе̌̌nova (vn Нежинская, DUS: 235; vrd I (M) Neežnova Neežnovaa čülä $\sim(\mathrm{V})$ Niežnõva M Nežnovo M Nežnovois-čülä); Lu Rüsümäe mõiza (VE X: 116); Lu ${ }^{\mathrm{ES}}$ Salazuu mõiza 'mõis Narva ja Kingissepa vahel'; Lu ${ }^{\mathrm{EK}} \mathrm{Ra}^{\mathrm{EK}}$ Savija $\sim$ Savi õja, Lu Savijaa mõiza (VE III: 104), Lu ${ }^{\mathrm{EK}}$ Savi-õja 'jõgi, küla, mõis ja veski', J Savi-õja mõiza (VE III: 104), Lu ${ }^{\mathrm{ES}}$ Savõjaa mõiza 'mõis Luuditsa ja Rüsümäe vahel' < savi + õja 'oja'; vn Лужиųа Лужиць (DUS: 189 jj, 235); Lu ${ }^{\mathrm{ES}}$ Vilikkaizii mõiza 'mõis Villikkala küla lähedal', (M) Vilikää mо̃iza (VE X: 71); vrd vn Великина (DUS: 234). 
Ičäpäivä mõis oli tegelikult Luizina mõisa karjamõis (DUS: 161). Saviõja mõis paikneb Lužitsa jõe vasakul kaldal, üle jõe vastaskaldal asus Saviõja küla (DUS: 191), mille järgi saigi mõis oma vadja nime, seevastu vene nimi pärineb jõelt. Salazuu, õigemini Salasuu nime kandnud mõis asus Lauga vasakul kaldal, jäädes Kingissepast loodesse. Mõis paiknes tänapäeva Sala küla territooriumil ja kandis Peter Köppeni järgi nime Salansuu, kus peale venelaste elas alla poolesaja ingerisoomlase (savakod) (ETK: 86; vt ka Dmitrijev 2016: 253). Nimi seostub samanimelise Lauga lisajõega (vn Солка), sisaldades osiseid Sala ja suи 'ka: jõesuu'. Solka voolab alamjooksul mitu kilomeetrit Luuga jõega rööpselt, mistõttu Sala küla asub nagu poolsaarel peajõe ja suhteliselt väikese lisajõe vahel. XVI sajandi kirjapanek Salussus võimaldab oletada jõenimeks Salo, vrd ee salu, sm salo jt (vt EES: 458).

Ka XX sajandil oli Vaipoole vadjalastele tuntud külanimi J Lu Salasuu 'küla Narva ja Kingissepa kandis'. A-lõpuline nimekuju on tekkinud vene keele mõjul. Soikkola poolsaarel asuva kirikumäe (vrd vdj *čerikoomäči) järgi sai nime Lu ${ }^{\mathrm{ES}}$ Čerikoomäeе mõiza 'mõis Soikkolas'; vn Анненгоф (DUS: 185 jj). Nikolai Imetegija õigeusukiriku asukoht on andnud isuri nime ka endisele külale (is ${ }^{\mathrm{N}}$ Kirgomkülä; vn Сойкино), vrd kirkko 'kirik'.

Mõisaomaniku nimega seostuvad järgmised toponüümid: $\mathrm{Lu}^{\mathrm{ES}}$ Ivan Kost'aa mõiza 'väike mõis Liivčülä metsa ääres'; Lu ${ }^{\mathrm{EK}}$ Korfi 'mõis Narva lähedal'< Korff; Kõ ${ }^{\mathrm{EK}}$ Luizina, (I) ${ }^{\mathrm{EK}}$ Luiizina 'Luizina mõis'; Li Piippinaa mõiza (VE XV: 54), Lu ${ }^{\mathrm{ES}}$ Pippinää mõiza 'mõis Lauga ääres' < Bippen; $\mathrm{Lu}^{\mathrm{ES}}$ Šleiterii mõiza 'mõis Soikkola poolsaarel'; $\mathrm{Li}^{\mathrm{ES}}$ Teksterii mõiza. $\mathrm{Ku}^{\mathrm{P}}$ Reezovaa moisio võib olla seotud Rezvõide suguvõsaga, kellele kuulus Marienhofi ehk Uue Sala mõis Lauga ääres (vt DUS: 9 jj, 266). Paraku jääb osal selle rühma kohanimedest mõisa asukoht ja omaniku nimekuju selgitamata. Teadaolevalt on Luizina nimi pandud selle omaniku Karl Pritwitzi naise Louisa järgi (vn Луизино, varem Родники, sealsete lätete järgi; DUS: 161; vrd родник 'allikas'). Nime Pippinää mõisa puhul pole selge, kas see tähistas Korovina või Preobraženskaja mõisat, kuid toponüüm lähtub vendade Bippenite nimest (vt allpool).

Ülejäänud mõisanimed on kas muud või ebaselget algupära. Tänapäeva Rajo küla piiridesse jääb Lauga paremal kaldal asuv Korovina mõis (algul karjamõis) ja üle jõe vasakul kaldal Preobraženskaja, mis kuulusid vendadele Bippenitele (vt eespool). Vadjalased kasutasid nendest rääkides vene keelest laenatud nimesid: vastavalt Li Korovinaa mõiza 
(VE XV: 54), Lu ${ }^{\mathrm{ES}}$ Korovinaа mо̃iza, vn Коровина $\sim$ Коровино (DUS:

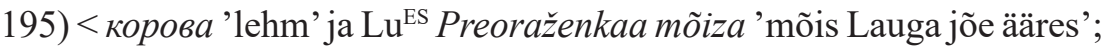
$\mathrm{J}^{\mathrm{EK}} \mathrm{Li}^{\mathrm{EK}} \mathrm{Lu}^{\mathrm{EK}}$ Preobraženkka, vn Преображенская $\sim$ Преображенский (DUS: 195) < преображение 'ümberkujundamine; Issanda muutmine'. $\mathrm{Ku}^{\mathrm{P}}$ Priilitša a moisio tuleneb venekeelsest mõisa- ja külanimest Приречьe 'Jõeäärse' (vt TKR: 26). Lu' ${ }^{\mathrm{ES}}$ Jaa mõiza 'mõis Narvuzi lähedal' päritolu jääb selgituseta.

\section{Külanimed}

Vadja külade (vdj čülä) nimed on mitmesugust päritolu. Kuna seal kandis räägitavad läänemeresoome keeled on omavahel väga sarnased, siis on täpsema päritolu kindlakstegemine sageli raskendatud. Enamikul küladel, kus on elanud vadjalasi, on nimi tulnud kas vadja või muust läänemeresoome keelest (isuri, soome), nagu Kõrvõttula, Kazikko. Ent osa külanimesid oli vadjalaste suus tuntud ainult vene keele vahendusel, nt Koslova (vrd vn Гостилово) јa Luиditsa Luиttsa (vn Лужицьь). See võib olla tingitud tõigast, et omanimi on ajapikku ununenud. On teada kohanimesid, millest on säilinud nii varasem läänemeresoome variant kui ka hilisem venepärane nimi, mis alati ei ühti tänapäevase puhtvadjakeelse nimega, kuid nad on siiski usutavasti läänemeresoome päritolu, nt Kikeritsa, Undova.

Allpool tuleb juttu külanimedest tähendusrühmade kaupa. Siinpuhul eristatakse ühelt poolt külasid, mis XVII-XX sajandi andmeil olid asustatud vadjalastega, teisalt aga valikuliselt huvipakkuvamaid külasid XX sajandi Vadjamaa naabrusest. Peaaegu kõik külanimed pärinevad Eesti Keele Instituudi kohanimekogust, mistõttu kollektsioon jääb märkimata. Iga poolpaksus kirjas märksõna algab enamasti laiemalt kasutatava või mõnel juhul oletatava külanime variandiga. Üksikjuhtudel on võrdusmärgi järele lisatud käsitletava külanime tuntum kuju. Sulgudes on toodud venekeelne ametlik nimi. Edasi järgnevad ajaloolised ja murdelised nimekujud.

\subsection{Vadjalastega asustatud külade nimed}

Vadja külad on saanud nime 1) muistsete isikunimede ja rahvanimetuste, 2) kristlike isikunimede, 3) ümbruskonna omaduste, 4) küla asendi ning 5) muude iseärasuste põhjal. Mitme külanime päritolu pole seni õnnestunud välja selgitada. 


\subsubsection{Muistsetest isikunimedest ja rahvanimetustest tuletatud külanimed}

Ühe tähendusrühma moodustab inimene või inimkooslus (pere- või sugukond), mispuhul külade nimed tulenevad isikunimedest. Nendega võivad liituda -la $\sim$-lä, -loiz $(<-$ loinõ $<-l a+-n e \sim n \tilde{)}),-n e:-z e e \sim-n \tilde{o}$ : $-z \tilde{o} \tilde{o},-s i \sim-z i$ (enamasti ne- $\sim$ nõ-sõnade mitmusetüvi) ja -ve $\sim-v \tilde{o}$, nagu toponüümides Iivanaisi, Kattiloiščülä, Kukkuzi, Kõntuvõ ja Pontizõõ (vt Ariste 1967: 80, 83). Seega on osa kohanimesid sekundaarsed nimed, st põhikohanime tuletised. Külanimede alussõnadena saab eristada muistseid isikunimesid ja kristlikke eesnimesid. Muistsete isikunimedega seostuvad oletatavasti *Assila, Ičäpäivä, Iltovõõ, Kukkuzi, Lempola, Pontizõõ, Valgovitsa ja Villikkala.

*As(s)ila *As(s)izi = Luuditsa. Ajalooline nimekuju: 1676 Asinits (OBG). Rootsiaegse kaardi toponüüm kujutab endast tõenäoliselt venekeelset nimekuju, mis koosneb läänemeresoome sõna sisaldavast põhiosast ja vene liite -uць $н$-lisest teisendist. Näiteks tuleneb vps Мустиничи isikunimest *Must $\sim *$ Mustoi; liidet -uщ̧b peetakse - ичu variandiks, mis on tekkinud vene murrakutele omase häälikumuutuse $\check{c}>c$ (vn цุоканье) tagajärjel (Mullonen 2002: 85, 88). See sufiks esineb sageli asulanimedes, tähistades selle isiku järeltulijaid, kelle nimi on toponüümi põhiosas, olgu see siis isa, vanaisa või mingi muu eellane (Kartavenko 2011: 317; Vagner 2014: 339). Vadja külanime põhiosa võib lähtuda läänemeresoome antroponüümist, vrd lv As(e) ee, lv Asse ee Assi ee, lv Asso (Stoebke 1964: 16-17). See esineb ka eesti külanimedes Assaku ja Assikvere (vt EKNR). Vene sufiksile võib vastata vdj -la või -zi. Soomes esineb külanimi Asila (1664 Asilaby), mida peetakse *Asikkala või *Asiala (> Asiala Asialankylä) lühenduseks (SPK; AH). Ilmselt kuulub seegi kokku uuritava vadja külanimega.

Ičäpäivä (vn Иципино). Varasemad kirjapanekud: 1500 д. Ичяпово Пиккуевы Горы (NPK: 509), 1618-1623 Itzepina By (JI: 31), 1676 Itsepinaby (OBG), 1684 Muskina Izepina (Mikkola 1932: 36), 1867 Dorf Jzypino (ETK: 20). Murrakuvariandid: J I K M Ičäpäivä, J Ičäpäivää čülä $<$ < ičä 'iga' + päivä 'päev'. Külanimi tuleneb eelkristlikust päivä-osisega isikunimest (EO: 5-6; Ariste 1967: 83). Asjaomane muistne isikunimi on registreeritud mitmelt läänemeresoome rahvalt ja saamidelt (vt Stoebke 1964: 85-86). Sellega on kõige sarnasem vanim, 1500. aasta nimekuju. Isikunimega on liitunud küla asendit näitava mäe nimi (vrd pikku'väike'), 
mis on ühes hilisemas revisjonikirjas esitatud ainukese külanimena. Hiljem on tõenäoliselt venelaste suus lühenenud isikunimekujule *Itsepa liitunud vene sufiks -in-, mis näitab kuuluvust, vrd nt nап-ин-а шляпа 'isa kaabu'

Iltovõ õ (vn Ундово). Varasemad kirjapanekud, vt Undova. Murrakuvariandid: (K-Alava) Illo, K-Kettunen Illoo čülä, P Iltovõ, K-Kettunen Iltovõi, (M) Iltõvõõ čülä (VE XIV: 144). Ariste (1967: 80, 83) järgi lähtub külanimi tõenäoliselt eelkristlikust nimest, millele on liitunud külakogukonda tähistav genuiinne kollektiivsufiks $-v e \sim-v \tilde{o}$. Võib oletada, et Illo $(<*$ Illoi) on skandinaaviapärane isikunimi (vrd Illa, Ille), mis on andnud nime näiteks Soomes asuvatele Illo-nimelistele küladele (vt SPK: Illoinen). Teisalt pole vadja toponüümi puhul välistatud õigeusu isikunimest Ilja tekkinud läänemeresoome variant (vt KK: 148: Illonsaari). Ehk tuleks vadja ja soome nimede valguses veel kord üle vaadata ka Eesti Ill-tüveliste toponüümide, eriti Illuka ja Illuste etümoloogia (vt EKNR).

Kukkuzi (vn Куровицы). Varasemad kirjapanekud: 1571 Куровичи на Луге, 1585, 1586 Kukulla, 1589 Kuckuk̈̈lle (Dmitrijev 2016: 254, 262), 1618-1623 Kurouitza By (JI: 195), 1676, 1678, 1684 Kuckus (GCI; OBG; Mikkola 1932: 35), 1705 Кукусь (GTI), 1867 Kurowitz (Kуровиць) (ETK: 40). Murrakuvariandid: P Ra Kukkozi, Ku Lu Kukkuzi, Lu Kukkuzi čülä, (J) Li Lu Kukkõzi. Külanimi seostub üldsõnaga kukko kukkõ 'kukk' (Ariste 1967: 83). Seega on tegu isikunimega (täpsemalt lisanimi) või on külaasukaid iseloomustanud kukkede rohkus, vrd sm Kukola, Kukonkylä, Karjala kannase Kukkola (vt KK: 226; SPK). Nii vdj -zi kui ka vn -(в)uu̧bl osutavad pigem esimesele võimalusele. Seega lähtub Kukkuzi nominatiivsest suguvõsanimest $<*$ Kukkozõd $<$ kukko $\sim$ kukkõ 'kukk', vrd ka sm Kukkosensaari (AH). XVIII sajandi alguse nimekujud kajastavad kohalikke keeli. XVI sajandi üleskirjutus taandub umbkaudsele nimekujule *Kukookülä 'Kukeküla'. Eestiski on mitu Kuke-nimelist küla (vt EKNR). Vene külanimi on otsetõlge vadja nimest, tulenedes üldsõnast $\kappa y p$, mille üks tähendusi on 'kukk' (SRN XVI: 106).

Lempola (vn Раннолово). Varasemad kirjapanekud, vt Raanala. Murrakuvariandid: K L (Lu) P Lempola čüla, M Lempoloiščülä (VE II: 39). Külanimi on tuletatud kohta näitava sufiksi -la vahendusel *lempi-tüve sisaldavast isikunimest, vrd sm 1571 Lempoi, lv 1564 Lempe jt (Stoebke 1964: 46, 95 jj). *Lemp-tüvelised kohanimed on levinud nii Eestis kui ka Soomes ja muudelgi läänemeresoome aladel, nt ee Lembevere, sm Lempoisten kylä (vt EKNR, KK, SPK). 
Pontizõõ (vn Понделево). Varasemad kirjapanekud: 1618-1623 Pondino By (JI: 54), 1676, 1678 Pondilla (OBG; GCI), 1867 Dorf Pontila (По́ндилово) (ЕTK: 20). Murrakuvariandid: K X-Kettunen Pondilova, (Po) Ponti, Po Pontii, (M) Po Pontiloisčülä, (Kõ)-Kettunen Pontisi, K Pontisii, Kõ Po V Pontizõõ, Po Pontizõõ čülä, P Pontovõõ, Po Pontovõõ čülä. Kohanimesufiks -la on säilinud tänaseni venekeelses toponüümis. Seega oli muiste kasutusel kaks nimeteisendit. Ariste (1967: 83) järgi pärineb külanimi tõenäoliselt eelkristlikust isikunimest. Ehk on siis tegu sama tüvega mis eesti isikunimes 1539 Ponnekenn (Stoebke 1964: 64).

Suur-Narvuzi (vn Большое Кузёмкино). ${ }^{4}$ Varasemad kirjapanekud: 1582 Kusomkyler bÿ, 1584 Narues, 1585, 1586 Narffwes, 1589 Naruitz (kõik viis nimekuju Dmitrijev 2016: 251 järgi), 1618-1623 Kusemkino by (JI: 196), 1676 Kosemkyna (OBG), 1684 Cosemkina (Mikkola 1932: 35, 36), 1867 Kosemkina (Кузе́мкина, Narwoisi) (ETK: 40, 134). Murrakuvariandid: $\left(\mathrm{J}^{\mathrm{Ts}}\right)$ Narizi, $(\mathrm{J})^{\mathrm{Ts}}(\mathrm{Ku})^{\mathrm{P}}$ Li Naruzi, J-Mägiste Narvusi, J Lu Narvuzi, Li ${ }^{\mathrm{ES}}$ Narvuzi (ka: VE X 125), Lu Narvuzi. Valentina Pilli on edastanud nime seletuseks muistendi, mille kohaselt soomlased sõitnud Laugat pidi ülesvoolu ja kohalike inimeste küsimusele sõidusihi kohta saanud vastuseks: $H a P y c b$, s.o 'Venemaale'. Küla venekeelse nime seostas Pilli Novgorodi vürstiriigi aegse antroponüümiga Kuzemka $\sim$ Kozemka (TKR: 22; vrd Bæklund 1959: 177, 178 Козма, Кузма, Кузимка). Narva nimi oletatakse pärinevat enamasti koske tähistavast sõnast (vt EKNR: Narva). Narvuzi lähedal mingit juga ei ole, mistõttu võib oletada, et küla asutasid Narva jõe äärsed elanikud *narvoizõd. Teisalt pole välistatud, et vadja toponüümi lähteks on muu apellatiiv või Skandinaavia isikunimi Narve, vt sm Naarva ja Narva (SPK).

Suur- ja Väike-Valgovitsa (vn Большие и Малье Валговищы) = Kõntu. Varasemad kirjapanekud: 1500 село Валговичи (NPK: 911), 1618-1623 Valgouitza By (JI: 54), 1676 Walgowits (OBG), 1678 Wolgowitzabÿ(GCI), 1705 Волговищьы (GTI), 1867 Dorf Pien Walgowitz (Мал. Ва́лговиць), Dorf Suur Walgowitz (Большие Ва́лговищьь) (ЕТК: 20). Murrakuvariandid: $\mathrm{Ku}^{\mathrm{P}}$ Suur Valgavittsa, $\mathrm{Ku}^{\mathrm{P}}$ Peen Valgavittsa, $\mathrm{P}$ Valgovittsa, Kõ Valkõvittsa. Tegu on läänemeresoomelise nimega, kuid vadjalased on selle venelastelt teiseselt omandanud. Barabaš on tõlkinud

4 Väike-Narvuzi (vn Малое Куземкино) rajati Suure-Narvuzi suure tulekahju järel XIX sajandi viimasel veerandil (TKR: 22). 
nime 'valge vits' (TKR: 32), vrd valkõa 'valge' + vittsa 'vits'. Tegelikult on -(в)uц̧a -(в)uщ̧ vene kuuluvust märkiv kohanimeliide, vt eespool Assila . Esiosa puhul vrd soome isikunimesid *Valkea ja Valkeapää ('valgete juustega inimene') ja Valko (Stoebke 1964: 173), soome toponüüme Valkeala ja Valkola (vt AH, SPK), samuti 1676 Walkoviby (<?*Valkovõ) Rattšina pogostis. Nagu Kattilagi puhul, on vadjalased pidanud Valgovitsa ametlikult eraldi külasid ühe küla otsteks: M Suur õttsa ja M Peen õttsa (VE X: 71), vastavalt siis Suur- ja Väikeots. Väike-Valgovitsa hävis Teise maailmasõja päevil.

Tiutitsõ (vn Tuymuщ̧ы). Varasemad kirjapanekud: 1500 Тютицุи (NPK: 568), 1618-1623 Tytitza By (JI: 70), 1676 Tutitsaby (OBG), 1678 Tötitsabÿ (GCI), 1684 Tyttiza (Mikkola 1932: 42), 1867 Dorf Tjutizy (Tютииьь) (ETK: 20). Selles külas on vadjalasi ainukesena maininud Köppen. Küla vadjakeelne nimi pole teada. Venepärast toponüümi saab ehk ühendada rahvanimetusega чyдb 'siin: vadjalane'. Rahvanimetusest tuletatud asulanimi võib osutada asjaomase rahvaga küla piiriasendile. Teisalt on võimalik võtta aluseks germaanipärane isikunimi Thiuda $\sim$ Tiude Tiuto, mis seostub omakorda gooti sõnaga thiuda $\sim$ tiuda 'rahvas', vrd sm Tiutinen, Tjuda (SPK). Lõpuks, sama lähet, kuid mitte eriti usutavalt on oletatud ka tšuudi tähistava vene sõna tekkel (Grünthal 1997: 164-165). ${ }^{5}$

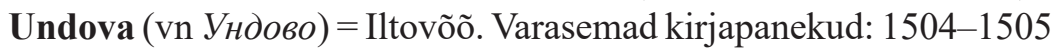
дер. Ундуево (ОРК: 22), 1618-1623 Vndoieuа By (J: 51), 1676 Ondowa (OBG), 1678 Ondofvabÿ(GCI), 1849 Undowo, 1867 Dorf Undowa (ETK: 20). Murrakuvariandid: $\mathrm{Ku}^{\mathrm{P}} \mathrm{P}$ Undova, (I) Undova (VE I: 241), J Undovaa čülä (VE VIII: 133), vrd ka is ${ }^{\mathrm{N}}$ Untova. Kettunen sidus uuritava vadja kohanime ning eesti toponüümid Undama, Undla ja Undva muistse isikunimega *Unto $(i) \sim *$ Unte(i) (EO: 83, 122-123, 258; vt ka Stoebke 1964: 102), vrd ka sm Untamala ja Unto (vt AH, SPK). Ariste (1964: 171) on viidanud eesti kohanimele Undla. Vadja küla varasem nimekuju võiks olla *Untoivõ, st ve- võ-liiteline. Vadjalased on sekundaarselt külanime üle võtnud venelastelt.

\footnotetext{
5 Samal ajal kirjutas tšuudi-sõnast Jorma Koivulehto (1997: 160), kes esitas ka põhjenduse muutusele alggermaani * peuđō $>$ muinasskandinaavia *bjuđa 'rahvas' (mitte ainult gooti). Koivulehto täpsustused muudavad ülimalt tõenäoliseks võimaluse, et see ligikaudu aastasse 600 rekonstrueeritav sõna on laenatud viikingite keelest muinasvene keelde. On loomulik, et 'rahva' all mõeldi esialgu põlisrahvast veetee ääres, kes ei kõnelnud ei muinaspõhja ega muinasvene keelt (retsensendi täiendus).
} 
Villikkala (vn Великино). Varasemad kirjapanekud: 1500 селичо Виликино (NPK: 907), 1618-1623 Villikina By (JI: 53), 1676 Willika (OBG), 1678 Willikinabÿ (GCI), 1867 Dorf Welikinä (Ви́ликино Ве́ликино) (ETK: 20). Murrakuvariandid: (Ja) (M) Po S Velikka, (M) Velikaa čülä (VE XV: 122), Lu Velikkä, (Kõ) Velikää čülä (VE IX: 40), $\mathrm{M}$ Vilikaa čülä, $\mathrm{Ku}^{\mathrm{P}}$ Villikkaisii (külä), P Villikkõvõõ čülä. Tamara Barabaš on edastanud muistendi, mis seostas küla nime Peeter Suurega Põhjasõja päevil (vrd vn великий 'suur'). Ta väitis vastu Tatjana Jefimovale, kelle järgi nimi tähendabki 'suur', ja esitas omalt poolt samuti ebaõnnestunud etümoloogia, mispuhul seostab külanime apellatiiviga villi 'vill, vistrik' (TKR: 32-33). Ariste (1967: 83) teatel pärineb toponüüm tõenäoliselt eelkristlikust isikunimest. Selleks sobiksid ee 1520 Villika, lv 1355-1362 Villika jt, mis kuuluvad läänemeresoome Vilja-nimepesasse (vt Stoebke 1964: 106). Soomes on sama päritolu kohanimed Viljakkala ja Villikkala (vt SPK). Samasse rühma kuuluvad ka Karjala kannase külanimed Vilakkala ja Villikkala; Saulo Kepsu oletab nende algkujuks vastavalt *Viljakka ja *Viljikka (vt KK: 499). Eesti toponüümidest võiks nendega kõrvutada külanime Villike, kuid sellele on esitatud teine, saksa etümoloogia (vt EKNR). Vadja küla $e$-line vene nimekuju on tekkinud oletatavasti великий mõjul.

*Vad'd'aa[čülä]. Ajalooline nimekuju: 1676 Wodja (OBG), 1678 wodia (GCI). Küla paiknes Jarvikoiščülä vastas teisel pool järve. Nime järgi otsustades oli tegu vadjalaste kunagise asukohaga, võib-olla piiriala külaga. Esimese silbi $o$ on tekkinud vene keele eeskujul. Kohanimi on suhteliselt hiline, tekkinud pärast seda, kui vdj-jj- oli arenenud $d j$-iks või d'd'-ks (vt ka Ariste 1965a: 99; autor seda nime ei käsitle). Hilisematel kaartidel küla ei näidata.

\subsubsection{Kristlikest isikunimedest tuletatud külanimed}

Ristiusunimedest on lähtunud Iivanaisi, Kliimettina, Mati ja Savvokkala.

Iivanaisi (vn Ивановское). Varasemad kirjapanekud: 1500 селио Иванково (NPK: 524), 1618-1623 Iwanofschi By (JI: 15), 1676 Ivanowskoi(OBG), 1678 Ivanofchoi (GCI), 1684 Iwannovski (Mikkola 1932: 34), 1834 Ивановская (TKP), 1867 Dorf Iwanowskoje (ETK: 20). Murrakuvariandid: I Iivanaisi Iivanaisii. Ariste (1967: 83) järgi on küla saanud nime kristlikust eesnimest Iivana. 
Kliimettina (vn Климотино). Varasemad kirjapanekud: (1500) село Климятино (NPK: 541), 1618-1623 Klimetina by (J: 24), 1676 Klementia (OBG), 1678 Climentino (GCI), 1684 Clementina (Mikkola 1932: 37), 1705 Клементино (GTI), 1867 Klímatina (ETK: 20). Murrakuvariandid: (I) Kleemettina (VE XIV: 152), J Kliimettina. Vadja külanimi pärineb vene nimest, mis lähtub kristlikust eesnimest Климентий. Vene nimede erinev vokaalistik sõltub vist murdeerinevustest. Eestis on sama päritolu nimega Kliima küla (vt EKNR).

Mati (vn Матия). Varasemad kirjapanekud: 1500 д. Матея (NPK: 924), 1618-1623 Mattia By (JI: 52), 1676 Mallekyla (OBG), 1678 Mattekÿla (GCI), 1867 Dorf Matti (Мámuя) (ETK: 20). Murrakuvariandid: (J) (Ja) (K) (Kõ) Lu M P Po S Mati, M P Matičülä, (Lu) Matičülä (VE IX: 58), J Matii čülä (VE VIII: 132), Lu Matii čülä, (K) Lu (M) (P) (Po) (S) Mativõ, Po S Mativõõ čülä, M (P) Mativõõ čülä (VE V: 145; VE IX: 176; VE XII: 287), Ku ${ }^{\mathrm{P}}$ Mat'śivee, Ja-Lensu Matti, M Matti Matti-čülä (VE IX: 25). Barabaš on tuletanud külanime õigesti isikunimest Matti (TKR: 34). Vdj Matte, vdj is Matti on tekkinud vene kristlikust nimest Mamфeŭ (Saar 2016: 170). 1676 Mallekyla on kirjaviga. Vrd ka sm Matti, Mattila jt (AH).

Savvokkala (vn Савикино). Varasemad kirjapanekud: 1618-1623 Safwukala By (JI: 58), 1676 Sawikylä (OBG), 1678 Savikÿla (GCI), 1705 Савіокіла (GTI), 1867 Dorf Sawikina (Са́викино) (ЕTK: 20). Murrakuvariandid: Po Savvokkaisi, Kõ (M) Po S Savvokkala, M Savvokkalaa čülä, $\mathrm{Ku}^{\mathrm{P}}$ Savvukkaisii, J Savukkaisii čülä, (Lu) M P Savvukkala, M Savvukkalačülä (VE II: 43). Kettunen on seostanud vadja külanime oletamisi sõnaga savakko 'savolane', Ariste aga kristliku eesnimega Savva (EO: 82-83; Ariste 1967: 83). Täpsemini võiks tegu olla sama nime oletatava teisendiga *Savvokka, millele on liitunud -la. Tänapäeva vene nimekuju osutab võimalikule eesnimeteisendile *Savvikka. Samas viitavad mõned XVII-XVIII sajandi kirjapanekud selgesti külanimele Savvičülä 'Saviküla', vrd vdj savi savvi 'savi', vrd sm Savikylä (AH). Kattila murde alal oli kasutusel mainitud üldsõna pika konsonandiga vorm. Siinpuhul võib varasemates kirjapanekutes olla tegu isiku- ja üldnime vastastikkuse mõjuga, mis jääb praegu täpsemini selgitamata. Mingit alust pole Jefimova oletusel, nagu külanimi võinuks seostuda Vaipoole Saviõja külast tulnutega; teisalt on ta pidanud lähteks vadja olematut sõna savka 'savi' (TKR: 34). 


\subsection{3. Ümbruskonna omadustest tuletatud külanimed}

Vadjalastel on külanimesid, mis tulenevad ümbruskonna omadustest, sh metsaliigist, mullapinna viljakusest, maastikuelemendi kujust. Sellesse rühma kuuluvad * Karakkola, Kazikko, Kattila, Kõntu, Liivačülä, Mahu jt.

*Karakkola (vn Краколье) = Jõgõperä. Varasemad kirjapanekud: 1618-1623 Krokolia By (JI: 56), 1676 Kroholia (OBG), 1678, 1684 Krokolia (GCI; Mikkola 1932: 35), 1867 Dorf Joепрегӓ (Короко́лье) (ЕTK: 20). Vene külanimi Краколье Караколье võib olla läänemeresoome algupära. Baranov on tuletanud külanime läbivoolava oja nimest Краколка ja taandanud selle sõnadele karu + kolkka 'nurk' (TKR: 41). Selline nimi ei sobi hästi väikesele veekogule. Pigem on oja nimi sekundaarne, sisaldades vähendusliidet. Siinpuhul võiks külanime samastada täpsemalt määratlemata läänemeresoome keele sõnaga *karakka karakko, vrd sm karahka karahko $\sim$ karakka $\sim$ karhakka (metateetiline) 'noor poolkuivanud kuusk; puuoks', mis on omakorda tuletis läänemeresoome lihtsõnast *kara, vrd sm kara 'kuivanud oks; risu; tapp; lukukeel; suguti jt', lüü karaoks 'puu kuivanud alumine oks', ee kara 'midagi rippuvat, sh suguti' (SSA I: 309). Soomes on mitu sama algupära kara-tüvelist toponüümi (vt SPK). Ei vadja ega isuri keelest pole sobivat sõna registreeritud. Seega, külanimi võis tekkida paigas, kus leidus palju kuivanud oksi, vrd Rüsümäči < risu (vt 5.2).

Kazikko (vn Березняки). Varasemad kirjapanekud: 1618-1623 Beresnägh Ödhe (JI: 54), 1705 Березова (GTI), 1867 Dorf Kasiko (Верезняки) (ETK: 20). Murrakuvariandid: M Kaazikkõvõõ čülä; J Ku${ }^{\mathrm{P}} \mathrm{Lu} \mathrm{M}(\mathrm{Ra})$ Kazikko, Ra Kazikoo čülä; vrd is ${ }^{\mathrm{N}}$ Kazikko. Külanimi pärineb üldsõnast kaazikko kazikko 'kaasik' (Ariste 1967: 83). Vene nimi on tõlkelaen, vrd березняк 'kaasik, kasesalu'. 1867. aasta Верезняки algustäht on tekkinud ladina tähestiku mõjul. 1705 Berezova on võrreldav vene apellatiiviga береза 'kask'. Eestis on mitu Kaasikuküla (vt EKNR).

Kattila (vn Котль). Varasemad kirjapanekud: 1500 Котел (NPK: 905), 1618-1623 Kattila By (JI: 49), 1676 Cattilaby (OBG), 1678, 1684 Cattila (GCI; Mikkola 1932: 32), 1705 Катилла (GTI). Murrakuvariandid: (J) I (Ja) K (Kõ) (L) (Li) Lu (M) P (U) Kattila, M Kattiloisčülä. Kettunen on kõrvutanud vadja toponüümi eesti kohanimega Katela, oletades mõlemal juhul lähtumist üldsõnast kattila 'katel' või isikunimest Katti, vrd katti 'kass', vrd samuti ee Kadiküla, Kadila ja Kassiküla (EO: 75; EKNR: 152, 181-182, 184). Kumbagi varianti ei eelista ka EKNR, ehkki nimeosiste katel ja pada esinemine on üldisem loodusnimedes. 
Venekeelsest külanimest lähtudes on seda toponüümi seostatud sõnaga котел kas tähenduses 'auk, milles aeti tõrva' või 'auk, milles sulatati soomaagist rauda' või tähenduses 'nõgu' (vt TKR: 33-34). Kattila paikneb paeklindil, mille juures laiub taevakaareni ulatuv madalam ala. Seetõttu tundubki viimane tähendus olevat tõepärasem. 1500. aasta nimekuju Котел lisab veendumust, et kohanimi ei lähtu isikunimest. Sama toponüüm esineb Ingerimaal mujalgi, nimelt Inkere ja Venjoki kihelkonnas (Kepsu 1990: 167). Kahjuks ei tunne siinkirjutaja nende külade maastikku, mis võinuks kaasa aidata Vadjamaa külanime etümoloogia täpsustamisele. Soome kohanimi Kattilainen on teist algupära, küll aga sisalduvat sm kattila 'katel', sh süvendit tähistava mõistena toponüümis Kattilakoski, vrd ka Kattilalaakso, Kattilanmäki jt (vt AH, SPK).

Kattila koosnes vadjalaste meelest kahest otsast, mis on ametlikult olnud eri külad, sh 1838 Малой Конец (OPG: 70), 1867 Dorf KleinKonez (ETK: 20), vdj Peenõttsa (Ariste 1967: 81), P Pienõttsa < peeni 'väike' + õttsa 'ots' ning 1838 Большой Конеч (OPG: 70); 1867 Kirchdorf Kattila (Котль) (ЕTK: 20), vdj Suurõttsa 'Kattila küla idapoolne ots', (K)-Mägiste, P-Kettunen Suurõttsa, P Suurõttsõvõõ čülä < suuri 'suur'. Ariste teatel (1967: 81) on Kattila küla kirdeots vadjalastel kandnud nime Kultamäči 'Kuldmägi'.

Kõntu (vn Валговицы). Varasemad kirjapanekud, vt Valgovitsa. Murrakuvariandid: (J) Kontu, (Lu) M Po S Kõntu, M Kõntuvõõ, Lu Kõntuvõõ čülä (VE XI: 178), M-Lensu Kõntuvõõ čülä, Kõnnuu čülä (Ariste 1967: 80). See puht vadja nimi lähtub mujalt registreerimata sõnast *kõntu (vt Ariste 1967: 83). Läänemeresoome sõna väljendab eesti keeles ühelt poolt väheviljakat, tavaliselt asustamata maad (kõnnumaa), teisalt aga kuiva, kõrget maad (kõnd), seevastu soome, karjala ja lüüdi sõnad tähistavad enamasti kodupaika, soome kontu lisaks turvast ja sood ning karjala kontu põldu ja kontošikko ebatasast maapinda (vt EES; SPK: Kontula; SSA I: 398). Vadja sõna täpsem tähendus jääb paraku teadmata, suurema tõenäosusega on ta samuti tähistanud mingite eriliste omadustega maad. ${ }^{6}$ Eestis on mitu Kõnnu küla (vt EKNR). Jõgõperä kandi Kontu on $o$-poolest isuri- või soomepärasus.

Kõrvõttula (vn Корветино). Varasemad kirjapanekud: 1676 Korvekyla (OBG), 1678 Korfwikÿla (GCI), 1834 Корвитило (ТKP), 1838

${ }^{6}$ Aastasadu eesti-vene-vadja-isuri segaasustusega Iisaku kihelkonnas on mõlemad lekseemid tähendanud aletatud maad (EMS IV: 256, 264; vt ka EMK: 169). 
Корвияпово (OPG: 70), 1867 Dorf Korwittina (Ке́рвотоло) (ЕTK: 20). Murrakuvariandid: J Korvõttula (VE VIII: 132), M Kõrvõttula (VE I: 169), (M) Kõrvõttulaa čülä (VE XII: 287). Ariste (1967: 83) teatel on külanime lähtesõnaks *kõrpi : kõrvõ õ 'kõrb : kõrve, põlismets'. Selles tähenduses pole vadja üldsõna registreeritud, küll aga ühe evangeeliumi tõlkes tähenduses 'kõrb : kõrbe'. Eestis on mitu Kõrveküla (vt EKNR) ja sage on see nimi ka Soome toponüümias (vt AH, SPK). Varasemad kirjapanekud osutavad analoogilisele nimele ka Vadjamaal - *Kõrvõõ čülä. Vene nimekuju pärineb mõnest läänemeresoome keelest, ent rahvaetümoloogiliselt seostatakse seda siinkirjutaja teatel tänini sõnaga корвет 'korvett'. 1838 Корвияпово keskosa jääb praegu seletuseta.

Liivčülä (vn Пескu). Varasemad kirjapanekud: 1618-1623 Pesock By (JI: 56), 1676 Päsobky (OBG), 1867 Dorf Liwakylä (Пескu) (ЕTK: 20). Murrakuvariandid: M Liivačülä, J Li Lu Liivčülä, J Liiv-čülä, $\mathrm{Ku}^{\mathrm{P}}$ Liivkülä, Li Liivõčülä. Külanimi lähtub sõnast liiva 'liiv' (TKR: 41), mida näitavad ka varasemad kirjapanekud. Nimekujus 1676 Päsobky on tähed $b$ ja $k$ ära vahetatud. Vadjalastel on olnud kasutusel nii nimetavalise liitumisega (kui mitte väljajätteline) kui ka omastavaline vorm: Liivačüla Liivčülä. Eestis on mitu Liivat ja Liivaküla (vt EKNR; Ariste 1967: 83).

Lipkovitsõ (vn Липко́вицы). Varasemad kirjapanekud: 1500 селияо Лепково (NPK: 554), 1618-1623 Läpkouо By (JI: 70), 1678 Läpikowa (GCI), 1867 Dorf Lipkówitz (Липко́вицы Лебко́вицьь) (ЕTK: 20). Seda on ainult Köppen nimetanud vadjalastega asustatud külade hulgas. Vadjakeelne külanimi on talletamata. Usutavasti lähtub vene toponüüm vadja sõnast lepikko 'lepik'. Seega võinuks külanimi kõlada nt *Lepikoizi $<*$ Lepikoizõd. Eestis asub mitu Lepiku küla (vt EKNR). Lepikko küla pole tundmatu ka Soomes (AH). Vene liite -uщbı kohta vt Assila (5.1.1).

Luuditsa (vn Лужицы). Varasemad kirjapanekud: 1500 Лужыци на усть Луги (NPK: 910) või д. Лужый (NPK: 911), 1618-1623 Lusitsa By (JI: 55), 1676 Asinits (OBG), 1684 Luziza (Mikkola 1932: 35), 1867 Gut und Dorf Werchnije Lushizy, Dorf Nishnije Lushizy (ETK: 20, 134). Murrakuvariandid: (Lu) Lutsa, J Lu Luudittsa, J Luužitsa 'Alam-Luuditsa' (VE VIII: 132), Lu Luužitsa, M Luužitsõvõõ čülä, (J) Ku ${ }^{\mathrm{P}} \mathrm{Li} \mathrm{Lu} \mathrm{(M)} \mathrm{Luu-}$ žittsa, J Luutsaa čülä (VE III: 104), Li Lu Luuttsa. Tänapäeva Luuditsa on tekkinud kolme küla ühendamisel. Nimelt liideti Luuditsaga aastatel 1861-1864 Saviõja ja 1970. aastal Liivčülä (TKR: 41). Luuditsat nimetati varem vene keeles ametlikult kui Нижние Лужиць 'Alam-Luuditsa'. 
Ülem-Luuditsa vadja nimi oli Rüsümäči (vt 5.2). Jefimova on seostanud Luuditsa nime sõnapaariga деревни лужские 'Lauga-äärsed külad' (TKR: 41), vrd Луга 'Lauga jõgi', toetudes siinpuhul vaheldusele $2 \sim \varkappa$. Nõnda väites paigutas ta küla Lauga kaldale, tegelikult asetseb see aga samuti Soome lahte suubuva Luuditsa (vn Лужица) veeres. Venepärane külanimi on tekkinud jõenimest, mis omakorda läheb tagasi apellatiivile лужица 'loiguke'. Teisalt, sufiks -uц̧a esineb vepslaste asualal sageli jõenimedes, milles ta võib, kuid ei tarvitse funktsioneerida mitte vähendusliitena, vaid formandina (vt Mullonen 2002: 73 jj vepsa ala kohta). Sel puhul võiks ehk arvestada lähtesõnaga лужа, mis 'vihmaveelombi' kõrval tähendab murdeti ka 'soine koht' (vrd Долгая лужа tõlkes 'Pikksoo' Pihkva oblastis). Voolab ju jõgi enamalt jaolt soisel alal. Luudittsa esineb ka lühenenud kujul Luuttsa. Vastavus vdj $d \sim$ vn $ж$ seostub ilmselt vene keelele omase vaheldusega. Eestis võib vadja külanimele mõnesugust analoogiat leida toponüümides Luuska, Luutsna ja Luutsniku (vt EKNR). Vt ka Assila.

Mahu (vn Подмошье). Varasemad kirjapanekud: 1500 селияо Подмошье (NPK: 501), 1618-1623 Podmossie By (JI: 14), 1676 Podmoisio (OBG), 1678 Mahokyla (GCI), 1684 Mauho Podomoisio (Mikkola 1932: 37), 1849 Mahu, 1867 Mahu (Пóдмошье) (ЕTK: 20). Murrakuvariandid: I $\mathrm{Ma}^{\mathrm{K}}$ Mahu, $\mathrm{Ma}^{\mathrm{K}}$ Mahuu čülä, (I) Mahuvõ (VE I: 238); Mahuvõ̃ čülä (Ariste 1967: 83). Kettunen on võrrelnud vadja külanime eesti samakõlalise toponüümiga, oletades nende lähtesõnaks maho 'aher' (EO: 91-92). 1676. aasta nimekuju ei kätke soomepärast sõna moisio 'mõis', mis on laenatud ka vadja keelde. Подмошье tähenduseks on 'Sooaluse' < под 'all' + мох 'soo', vrd põhjavene nодмошье 'sooäärne maariba' (SRN XVIII: 308-309; SRG IV: 646).

Pihlaala (vn Пиллово). Varasemad kirjapanekud: 1500 село Пилола (NPK: 907), 1591 Pilela (Mikkola 1932: 28), 1618-1623 Pilola By (JI: 59), 1676 Pillolaby (OBG), 1684 Pillala (Mikkola 1932: 32), 1867 Dorf Pihlala (Пйллово) (ЕTK: 20). Murrakuvariandid: Ku ${ }^{\mathrm{P}}$ Pihlaa, K L (M) (P) Pihlaala, J Pihlaala (VE VIII: 133). Külanimi tuleneb apellatiivist pihla 'pihlakas' (TKR: 34; Ariste 1967: 83). Ka Eestis ja Soomes leidub mitu Pihl-tüvelist toponüümi (vt AH, EKNR). Eesti ja vadja nimede keskel asuv $h$-häälik on jäänud võõramaalastel nii siinpuhul kui ka enamasti mujal märkamata ja märkimata.

Pustomerža $($ vn Пустомержа) = Pustoperä. Varasemad kirjapanekud: 1618-1623 Pustamerssa By (JI: 163), 1684 Pustamerse (Mikkola 
1932: 33), 1867 Pustoperä (Пустомержа, Онетопель [peab olema Онстопель]) (ЕTK: 134, 135). Seal on vadjalasi registreeritud ainult XVII sajandil. Külanimi võib tuleneda sõnadest puusta 'tühi' (< vn nycmoŭ) ja ?märčä : märdžää 'märg'.

Saviõja (vn Глинки). Varasemad kirjapanekud: 1838 Глинки (OPG: 68). Murrakuvariandid: Lu Savija, J Savijaa čülä (VE III: 105), Lu Ra Saviõja, Lu Savi-õja, Lu Saviõja čülä, Lu Saviõjaa čülä. Kunagine küla (vt Luuditsa) on saanud nime läbivoolava Saviõja 'Savioja' järgi, vrd $\mathrm{Lu}^{\mathrm{EK}}$ Savija, $\mathrm{Lu}^{\mathrm{EK}} \mathrm{Ra}^{\mathrm{EK}}$ Savi õja, Lu ${ }^{\mathrm{EK}}$ Savi-õja $\sim$ Savi õja jõki. Alussõna sau $\sim$ savi esineb ka paljudes Eesti toponüümides (vt EKNR: Saviaugu, Savikoja jt). Ka sm Savio tuletatakse varasemast nimekujust Savioja (SPK, vt ka AH).

Suur-Rasi (vn Большая Рассия). Varasemad kirjapanekud: $1500 \partial$. Расья (NPK: 908), 1618-1623 Rasia Bollsaia (JI: 51), 1676 Raskabolsoi (OBG), 1678 Rasskabolsoi (GCI), 1834 Чухонская Большая Рассия (TKP), 1867 DorfRasi (Чухонская Ра́ссия) (ETK: 20). Murrakuvariandid: $\mathrm{Ku}^{\mathrm{P}} \mathrm{M}$ Rasi, M Rasičülä, (M) Rasivõõ čülä (VE IX: 181), J Raziičülä, $\mathrm{Ku}^{\mathrm{P}}$ Soomee Rasi, Lu Soomõõ Rasi (VE XVI: 255), M Suur-Rasičülä. Köppeni ajal elas Suur-Rasis 20 vadjalase seas 75 savakko-soomlast. XX sajandiks olid vadjalased Suur-Rasis ilmselt hääbunud, sest seal teati elanud olevat üksnes soomlasi (VE, sealsamas). ${ }^{7}$ Külanimi tuleneb tõenäolisemalt hääbunud vadja üldsõnast * rasi, mille vasted on sm rasi rasikaski 'üle aasta põletamata alemaa', vähem tõenäoliselt aga taimenimetusest rasi [tähendust pole antud] ${ }^{8}$ või isikunimest, vrd ee Rasivere, Rassi; sm Rasi, Rasila, Rasimäki jt; is ${ }^{\mathrm{N}}$ Razi 'mingi metsa nimi' (vt EO: 275-276; EKNR: Rasivere). Uuritavat külanime pole võimatu tuletada ka eesnime Erasmus rahvapärasest kujust Rasi (vt KK: 378, Rasila). Sel puhul polnud esialgu tegu vadja toponüümiga. Tähejärjend $k a$ vanades kirjapanekutes ja Barabaši pakutud sm rasha 'tühermaa' (TKR: 34) jäävad arusaamatuks.

7 XVI ja XVII sajandi alguse vahemikus rajatud Väike-Rasi küla (1618-1623 Rasia Mensaia (JI: 51), 1676 Raskamensoi (OBG), 1678 Rasskamensoi; M Peen-Rasi. $(\mathrm{Ku})^{\mathrm{P}} \mathrm{Lu}$ Vennää Rasi (VE XVI: 255)) asustasid venelased.

8 See on tõenäoliselt Elias Lönnroti mainitud sm rasi 'vääveltulikas (Ranunculus nivalis)' (SRS II: 367). 


\subsubsection{Asendist tuletatud külanimed}

Küla asendiga seostuvad Jarvi, Jõgõperä, Čerikkočülä, Mäči, Mäčive, Pustoperä ja Rajo. Enamik neist on uuema aja vähe kasutatud paralleelnimed (v.a Jõgõperä ja Rajo).

Jarvi = Jarvikoiščülä. Varasemad kirjapanekud: 1676 Järvikylä (OBG), 1678 Jerviküla (GCI). Murrakuvariandid: M S Jarvi Järvi. Ühelt poolt on võimalik, et külanimi on saadud asendist järve ääres (Ariste 1967: 83), teisalt võib aga olla tegu üsna varajasest ajast pärineva pika toponüümi lühendteisendiga.

Jõgõperä (vn Краколье). Varasemad kirjapanekud: 1867 Dorf Joenрегӓ (Короко́лье) (ЕTK: 20), vt ka Karakkola (5.1.3). Murrakuvariandid: P Jegõperä, M P Jegõõperä, (Ku) ${ }^{\mathrm{P}}$ Joeeperä, (Ra)-Lensu Jõgaperä, J Li Lu Lu-Lensu (Ra) Jõgõperä, J Js Jõgõ-perä, J Jõgõperää čülä; (J) K Lu Jõgõõperä, M Jõgõõperää čülä (VE II: 47), vrd is ${ }^{\mathrm{N}}$ Joemperä. Külanimi tuleneb liitsõnast jõki : jõgõ 'jõgi' + perä 'pära, tagaosa; kaugemal asuv'. Ariste (1967: 83) on esitanud võrdluseks ee Jõepera ja sm Joenperä.

Čerikkocülä = Jõgõperä. Murrakuvariant: Li Čerikkočülä, mis pärineb sõnast čerikko 'kirik' ja märgib küla, kus asub kirik. Ka Eestis on mitu Kirikuküla ja Soomes Kirkonkülä (vt AH, EKNR).

Mäči = Ičäpäivä. Murrakuvariant: I Ma Märči. Nõnda nimetatakse seda küla mäekünka järgi, millel küla paikneb, vrd mäči 'mägi'.

Mäčive = Kattila. Murrakuvariant: (M) Mäčive. Tuleneb samast sõnast mis eelmine külanimi, kuid talle on liitunud -ve. Vrd ka (M) Mäčivee ranta 'mäginurk Kattilalt Kingissepani'.

Pustoperä (vn Пустомержа). Varasemad kirjapanekud, vt Pustomerža. Köppeni mainitud Pustoperä (Пустомержа) võib pärineda isuritelt, vrd vdj is perä 'pära, tagaosa; kaugemal asuv'. Osis pusto- on pärit vene nimest, vrd is puusta 'tühi'.

Rajo (vn Межняки). Varasemad kirjapanekud: 1905 [nустошь 'kõnnumaa'] Межник Нижняя Галика. Murrakuvariandid: Lu Ra Rajo, Lu Rajo čülä, Li Lu Rajočülä, $\mathrm{Ku}^{\mathrm{P}}$ Rajoi külä, $\mathrm{Ra}^{\mathrm{ES}}$ Rajoo čülä. See küla rajati XX sajandi algul Jõgõperäl juhtunud suure tulekahju tagajärjel. Vadja nimi on tuletatud liite $o-\left(<*_{-} o i\right)$ abil sõnast raja 'piir; ääremaa' (vt ka Ariste 1967: 83). Baranov on väitnud, et is Rajo on tõlkelaen vene keelest (TKR: 41). Apellatiiv межник межняк tähendab piiri ja põllupeenart (SRN XVIII: 88-89). Eestis leidub mitu Rajaküla (vt EKNR). 


\subsubsection{Muud ja ebaselget päritolu külanimed}

Siinkohal käsitletakse eelmistest tähendusrühmadest välja jäänud vadja külade nimesid. Nendest enamiku etümoloogia on vähemal või suuremal määral ebakindel.

Baabina $=$ Jarvikoiščülä. Murrakuvariandid: $\mathrm{J} \mathrm{Ku}{ }^{\mathrm{P}} \mathrm{Lu} \mathrm{M}(\mathrm{P})$ Baabina, (I) Baabina (VE I: 239), P Baabinaa čülä. See on laenatud venekeelsest nimekujust, vrd баба 'eit; vanaema'. Vadjalased on tarvitanud seda harva. Vene nime on mõjutanud vadja toponüüm (vt allpool), sest muistendite järgi elanud küla kõrval olevas järves järveema (Ariste 1964: 167, 170). Vadja viiendikus, sh Ingerimaal, on asjaomane külanimi laialt levinud (KK: 89).

Jarvikoiščülä (vn Бабино). Varasemad kirjapanekud: 1618-1623 Leuontieuo Osero By (JI: 57) või Babiuo [peaks olema Babino] Ödhe (JI: 112), 1676 Järvikylä (OBG), 1678 Jerviküla (GCI), 1834 Бабино (TKP), 1867 Dorf Babina (Ба́бино) (ETK: 20). Murrakuvariandid: P Jarvigoičülä, M Järvigoiščülä, K Jarvikois-čülä, L M Jarvikoiščülä, M Jarvikoščülä; Jarvigoisi Jarvigoisii čülä; vrd is Jarvikoiskylä Jarvakaiskylä (Ariste 1964: 167). Külanimi on sekundaarne, tulenedes järvenimest, mis on saanud omakorda alguse apellatiivist *jarvigoin $(\tilde{o}): *^{*}$ jarvigoizõ õ 'järveema, järvehaldjas', otsetõlkes 'järvelane, [järveelanik]'< jarvi + go + in(o) , vrd ka jarvi-emä (Ariste 1964: 170).

Kerstova (vn Керстово Кёрстово). Varasemad kirjapanekud: 1500 село Керстово (NPK: 894), 1618-1623 (Kerstoua By) (JI: 173), 1676 Kirstufwaby(OBG), 1684 Kirstova byy (Mikkola 1932: 33), 1705 Kiстова (GTI), 1867 Kirchdorf Kerstowo (ETK: 20). Murrakuvariandid: $\mathrm{K} \mathrm{Ku}^{\mathrm{P}}$ L Lu M P Kerstova, L Kerstovaa čülä. Vrd sm Kirstula. Vorontsov on külanime seostanud vanavene sõnadega кёрста керстица $\sim$ кереста, кресть 'rist' ning sõnadega ee kirst $\sim$ kerst, sm kirstu 'kast, kirst' (TKR: 54). Tegelikult tähendavad керста $\sim$ кърьста jt surnukirstu, керстииа aga anumat; кёрста 'haud' on hoopis põhjavene murdesõna (MSD I: 1411, 1206). Vdj kirstu ja is kirsto on viimase ajani säilinud tähenduses 'rõivaste jm tarvete hoidmise nõu'. $E$-line vorm viitaks nagu isuri keelele, kuid kogu keelealal oli tuntud kirsto; häälikumuutus ir $>$ er ei esine teistes Ingerimaa keeltes ja on tekkinud oletatavasti vene keele mõjul (Laanest 1966: 75-76). Seega ongi uuritavas külanimes toimunud areng vene keele pinnal, ent vanavene tüvest pole sugugi vaja lähtuda, sest see on laenatud balti päritolu läänemeresoome sõnast (EES: 161; ESR II: 225). 
Kikeritsõ (vn Кикерицьь). Varasemad kirjapanekud: 1500 Кикерицьь (NPK: 944), 1676 Kikeritsaby (OBG), 1678 Kikeritz (GCI), Kickeritza (Mikkola 1932: 33), 1867 Dorf Kikkerizy (ETK: 20). Köppeni ajal elas siin kõigest 38 vadjalast üle 200 savakko-soomlase kõrval. Vadja külanimi pole teada. Kõik varasemad kirjapanekud põhinevad vene keelel, liite -uu̧b kohta vt Assila (5.1.1). Formaalselt on võrreldavad ee Kikepera ja Kikivere, kuid ka nende päritolu on segane (vt EKNR). Pole selge, kas siia kuulub ka sm Kikkerlä (AH).

Koslova (vn Гостилово). Varasemad kirjapanekud: 1500 д. Гостилово (NPK: 526), 1618-1623 Gostilowa By (JI: 3), 1684 Gastilofwa (Mikkola 1932: 37), 1867 Dorf Kostlowa (Гостилово) (ЕTK: 20), Koslovan kylä (Kettunen 1915: 5). Vadja külanimi on vene toponüümi mugandus, mille korral vadjalastele arusaamatum nimi asendati tuntuma nimega, vrd vn козел 'sikk, sokk'. Vene kohanimi lähtub mittekristlikust antroponüümist Гостило, mis on moodustatud liite -ило abil, vrd Ярило, Войнило jt (Bæklund 1959: 67; SDL: 117; Kislovskoi 1974: 39). See tuleneb tõenäoliselt vanavene lekseemist $20 \mathrm{cmb}$ 'külaline; võõramaalane; kaupmees' (vt ESR I: 447).

Muuka (vn Мукково). Varasemad kirjapanekud: 1504-1505 дер. Будрино Мукуево (ОРК: 23), 1618-1623 Muckoieua By (JI: 57), 1676 Munkoa (OBG), 1867 Dorf Mukkowo (ETK: 20). Murrakuvariandid: Po Muuka, Po Muuka-čülä, (K) Ku ${ }^{\mathrm{P}}$ (P) (V) Muukkova, P Muukkovaa čülä, (Lu) M Muukõ, M Muukõ čülä, Lu Muukõõ čülä. 1504-1505. aasta andmeil asus külas двор ['majapidamine'] Ивашко да Гаврилко Мукуевь (OPK: 23), samal ajal paiknes mujal kandis соло [õigemini село 'küla'] Муковичи (OPK: 36). 1676. aasta nimekuju on ilmselt trükiviga. Eestis on vähemalt kaks Muugat, millest ühe nimi tuleneb sõnast muuk : muuga 'munk', teise küla nime algupära on ebaselge, sest seal pole teadupoolest munki elanud (EKNR: Muuga). Vaevalt et muuk-sõna oli selles tähenduses vadjalastele tuntud. Soomes on tänapäeval perekonnanimed Muukka (nt 1638 Oluf Mucka) ja Muukkonen ning külanimed Muukko ja Muukkola, mille aluseks on nimeuurija Viljo Nissilä oletamisi pidanud sõna muukka $\sim$ muukko 'muulane, mujalt elama asunu' (SSN: 540). See on usutav seletus. Vadjalastele oli tuntud ka otse vene keelest laenatud nimevorm.

Pummala (vn Пумалищы). Varasemad kirjapanekud: 1500 село Пумалищь (NPK: 906), 1618-1623 Pumolitza By (JI: 58), 1676, 1678 
Pumala (OBG; GCI), 1684 Pomala (Mikkola 1932: 32), 1705 Пумала (GTI), 1867 Dorf Pummola (Пу́молицы) (ЕTK: 20). Murrakuvariandid: (L) P Pummala, (M) Pummala (VE I: 169), P Pummalaa čülä, (J) Pummalittsa, J Pummolittsa. Barabaš on ühendanud külanime soome sõnadega puu 'puu' ja puumala [tõenäoliselt Puumala] (TKR: 34). Soomes on kaks Puumalat (nt 1541 Pomala), kuid nende puhul pole selge, kas isikunimi tuleneb kohanimest või vastupidi (vrd SPK ja SSN), ent seal on kohanimi Pummainen (AH). Vene liite -uubl kohta vt Assila (5.1.1).

Raanala (vn Раннолово). Varasemad kirjapanekud: 1500 село Ранола (NPK: 910), 1618-1623 Ranala By (JI: 59), 1676 Ranolla (OBG), 1678 Ranola (GCI), 1705 Рамола (GTI), 1867 DorfRanala (Ра́нолово) (ЕTK: 20). Murrakuvariandid: M Raanola, (M) Raanolaa čülä (VE XII: 297), M Raanoloiščülä (VE II: 39), J Raanula. Barabaš on otsinud algsõna soome keelest: tema järgi rannola [kas murdeline käändevorm] ranla [ilmselt trükiveaga] 'rand' (TKR: 34). Liide -la eeldaks tugevaastmelist vormi. Leningradi oblastis voolab jõgi nimega Ранница. Enamik kirjapanekuid lubab lähtuda esimese silbi pikavokaalisest kujust. 1705 Рамола on ilmselt trükiviga. Külanime päritolu on selgusetu.

Väike-Rud'd'a (vn Малое-Рудилово). ${ }^{9}$ Varasemad kirjapanekud: 1500 селио Рудъела Новая (NPK: 908), 1618-1623 Rudiala By Mensaia (JI: 63), 1678 Rudiala (GCI), 1705 Рудіала Менша (GTI), 1867 Pien Rudila (Малое Рудилово) (ЕTK: 20). Murrakuvariandid: P Peenrud'd'a, (K) $\mathrm{Ku}^{\mathrm{P}} \mathrm{P}$ (R) Rud'd'a, J Rud'd'aa-čülä, $\mathrm{P}$ Rud'd'avõõ čülä, $\mathrm{Ku}^{\mathrm{P}}$ Rudja. Sufiks -la esineb tänapäeval üksnes venekeelses nimekujus. Samanimeline küla (1676 Rudiala, 1704 Rudialahof, 1705 Рудіала) asus varem ka Villikkala ja Pontizõõ vahel. Külanime on üritatud ebaõnnestunult tuletada vene üldsõnast pyda 'maak' (TKR: 34). Ariste (1967: 83) on kõrvutanud vadja nime eesti toponüümiga Rutja. Häälikuajalooliselt see sobiks, sest varasemad kujud on kirjutatud $d$-ga (1498 Ruddy, 1652 Ruddi, 1871 Rudja). Eesti kohanime on seostatud soome murdelise apellatiiviga ruta (EKNR: Rutja). Sellise etümoloogia korral ei sobiks ta vadja nimega kokku, sest Rutja puhul tuleks oletada liittoponüümi *Ruta-oja vms. Seevastu vdj akkurrud'd'a 'aknalaud; aknalaua nurk' on kohanimega Rud'd'a raske ühendada semantiliselt, vastasel juhul pidanuks lekseem kunagi tähistama ka maanurka vms. Tähenduse poolest ei tundu sobivat

9 Suur-Rud'd'a küla (vn Большое Руддилово) oli mäletamatutest aegadest peale vene küla. 
ka häälikulooliselt ideaalne ee rudi : rudja 'puu millegi vajutamiseks või pressimiseks' (vrd rudima rudjuma 'vajutama, pressima') ega sm Ruija (1764 Rudia) 'ajalooline maakond Norra-Lapis, Finnmark', mille lähtesõnaks on oletatavalt deskriptiivne ruija $(t) \sim$ rutja $(t)$ 'virmalised' (vt EDW: 985; SSA III 100, 112).

\subsection{Teiste rahvastega asustatud külad}

Allpool tuleb juttu viiest Vadjamaa külast, mida on vadjalased kõige sagedamini nimetanud ja mis võiksid huvi pakkuda ka lingvistika seisukohalt. Siiski mainitagu kõigepealt väheseid vadjalastele tuntud Eesti külade nimesid: (Lu) Lohusuu (VE IX: 66), (Lu) Pühtittsa (VE IX: 195), $\mathrm{J} \mathrm{J} \mathrm{Js}^{\mathrm{Ts}}$ Sirentts 'Vasknarva' (< vn Cыренеu) ja J Lu Vaivaro, J J ${ }^{\mathrm{Ts}}$ Vaivõro 'Vaivara'. Viimane pärineb kohapeal kasutatavast eesti nimekujust Vaivaru (vt EKNR: Vaivara).

Kõhčizee (vn Косколово). Varasemad kirjapanekud: 1618-1623 Koschola By (JI: 55), 1684 Koskola (Mikkola 1932: 35), 1867 Koskinen (Косколово) (ЕTK: 41). Murrakuvariandid: (Ku) (Li) Koskine, Ku Koskizee külä, M Kõhčiloiščülä, J Li Lu (M)-Kettunen Kõhčizee, J Kõhčizõõ čülä (VE III: 29), Lu Kõhčizõõ čülä, Li Lu (Ra) Kõhtsõ, Li Lu Ra Kõhtsõõ čülä. Kõhčizee oli isuri küla (is ${ }^{\mathrm{N}}$ Koskizen külä). Toponüüm pärineb isuri keelest ja seostub samanimelisel jõel asuva kosega. Seda on nentinud juba Ariste (1964: 170; 1967: 83). Kosk-tüvi on läänemeresoomeline, kuid vadja ja isuri keelest kadunud. Nimi on esinenud nii liitega -la kui ka -ne : zen. Isuri toponüüm on olnud eeskujuks vadja nime moodustamisel hääbunud sõnast *kõhči : kõzgõ õ 'kosk' (arengulooliselt vrd kahči 'kask', vahči 'vask'). Eestis ja Soomes leidub rohkesti kosk-tüvelisi toponüüme (vt EKNR, SPK).

Lerrõba (vn Уcmb-Лyza). Varasemad kirjapanekud: 1584 Laukahus, 1585 Laukasw, 1867 Laukaansuu (Ocmpoв) (ETK: 40), 1940, 1958 посёлок Ленрыба. Murrakuvariandid: Lu Lerrõba Lerrõõba. Muistne läänemeresoome asula on sajandite vältel moodustanud eri asulakooslusi (vt Ust-Luga). Lerrõba on nõukogude ajal asutatud kalakombinaadi «Ленинградская Рыба» (Leningradi Kala) lühendnimi. Tänapäeval on Lenrõba Ust-Luuga sadamaasula kvartaleid. Vadja sõnakujus on $r r<n r$ tekkinud sarnastumise tagajärjel. Küla asub Lauga jõe suudmealal, sellest siis lähtuvadki varasemad kirjapanekud. 
Palokka (vn По́лучье). Varasemad kirjapanekud: 1500 Получье (NPK: 908), 1618-1623 Polutzie by (JI: 57) jt. Murrakuvariandid: J Ku ${ }^{\mathrm{P}}$ Li Lu P Palokka, I Palučči. Küla läänemeresoome elanikkonna kohta pole andmeid. Ilmselt on vadja toponüüm sama mis Kesk-Soomes Palokkajärve otsas paikneval Palokka külal. Soome külanime seostatakse kunagiste rannaäärsete alemaadega ja alepõletusega, vrd palokas 'põleng' (SPK). Venekeelne nimi seostub sõnaga лука 'luht jõekäärus; jõeäärne künnimaa; jõekääru kallas jt' (SRN XVII: 187), mis sobib küla tegeliku asendiga.

Rüsümäči (vn Верхние Лужсицы). Varasemad kirjapanekud: 1834 Верхние Лужииь (ТКР), 1867 Risumäki (Верхние Глинки) (ЕTК: 20). Murrakuvariandid: Li Lu M Risumäči, J Risumäe čülä 'Ülem-Luuditsa' (VE VIII: 132), Ku ${ }^{\mathrm{P}}$ Risumäki Risuumäki, Lu Rüsümä, Lu Rüsümä čülä, Lu Rüsümäči, Lu Rüsümä-čülä = Ülä-Lunžitsa, Lu Rüsümäe čülä. Tegu on kunagise isuri külaga, mis hävis Teise maailmasõja ajal. Nimi tuleneb isuri sõnast rüzü 'kuivanud oksad', milles $\ddot{u}$ on sekundaarne, vrd ee risu 'metsaalused pudemed; praht; tarbetu koli; roju', sm risu 'kuivanud oks', krj rizu 'kuivanud oksaraag; lagunenud ehitis' jt (EES: 431). Vadja nimekuju puhul pole selge, kas see oli ka vadja keeles $i$-line või on see laenatud ajal, mil isuri keeles polnud muutus $i>\ddot{u}$ veel toimunud. Kohanime saksakeelseks vasteks on antud 'Reisigberg' (Ariste 1967: 83), vrd Reisig 'hagu'. Külanimi on teisene, tulenedes mäekünka nimest. Eestis on lähiminevikus olnud ka mitu Risu-nimelist küla (vt EKNR).

Saira (vn Хаболово). Varasemad kirjapanekud: 1618-1623 Habala Ödhe (JI: 57), 1676 Habala (OBG), 1678 Haballab̈̈ (GCI) jt. Murrakuvariandid: J Kõ Li Lu M Saira, (M) Sairavõ, (M) Sairõvõ, M M ${ }^{\mathrm{ES}}$ Sairõvõo čülä. Küla läänemeresoome asukate kohta pole teateid. Toponüümi võib ehk seostada soome perekonnanimega Saira (1545 Hin Saira) ning kohanimedega Sairakkala, Sairio jt, mille päritolu pole päris selge, kuid ilmselt ei tulene nad üldsõnast sairas : sairaa 'haige', vaid neid võib ühendada pigem alamsaksa mehenimega Sairicho (SPK; SSN). Teisalt on kohanimeuurija Saulo Kepsu seostanud Karjala kannase jt külanimed Sairala ja Sairiala oletamisi lisanimega, mille aluseks võis olla siiski apellatiiv sairas (KK: 404). Kui mainitud seosed osutuvad õigeks, siis on järvenimi (Li Saira järvi, M Sairajarvi, M Sairavõõ järvi) sekundaarne. Käsitletavat toponüümi võib ehk kõrvutada ka Eesti endise küla nimega Saire (1637 Sayrakül). Kettuneni oletus selle seosest sõnaga saire $\sim$ saere 
'ting, täimuna' tundub olevat semantiliselt ebasobiv (EO: 173; EKNR: Saire). Venekeelne toponüüm tuleneb apellatiivist haapa 'haab', millele oli liitunud sufiks -la (vt ka TKR: 35).

\section{Külaosad}

Vadjalased on eristanud osasid (õttsa 'ots') eriti suurtel küladel. Laiemalt on tuntud Kattila (vt 5.1) ja Jõgõperä otsad, mis on olnud ka ajalooliselt eri külad. Tervikliku pildi saamiseks ongi otstarbekas käsitleda külaosasid külade kaupa.

Jõgõperäl eristati kaht suuremate ja laiemalt tuntud alaosa, millest üks oli mõisnike, teine aga riigi valduses. Esimene kandis nime Herravalta, vrd $\mathrm{Ra}^{\mathrm{EK}}$ Herravalta, $\mathrm{Ku}^{\mathrm{P}}$ Herraa valta, J Herraa valta (VE VIII: 143), $\mathrm{Ra}^{\mathrm{ES}}$ Herrvallaa ôtts (VE XV: 86), $\mathrm{J}^{\mathrm{ES}}$ Herrvalt, $\mathrm{J}^{\mathrm{Tsv}}$ Herr-valt, J Herrvalta (VE XVI: 74), J ${ }^{\mathrm{EK}}$ Her-valt, J ${ }^{\mathrm{EK}}$ Hervalta < herra 'mõisnik; härra; issand' + valta 'vald; valdus; võim'. Kroonule kuuluvat külaosa kutsuti J Kunikaa valta (VE III: 28), $\mathrm{Ku}^{\mathrm{P}}$ Kuningaa valta $<$ kunikaz 'kuningas'.

Mõisnike suguvõsa Korffide järgi on tekkinud nimi $\mathrm{J}^{\mathrm{ES}}$ Korffi õtts 'Jõgõperä osa'; Ra Korfii õtts (VE XV: 86), J Korfii õttsa (VE XVI: 74), J Korfõtts $\sim$ Korffõottsa (VE III: 28). Naaberpiirkond on andnud aluse toponüümidele $\mathrm{J}^{\mathrm{ES}}$ Halikaa õcc 'Jõgõperä küla ots, kus elas [tuntud keelejuht] Mari Petrova'; J Ra Halikaa õtts (VE III: 28; VE XV: 86), J Halikaa ôttsa (VE XVI: 74) ja Takavellää õtts (VE III: 28), Takaväll’ää ócca (Ariste 1967: 81).

Kohanimi Halikk- tähistab mitmesuguseid objekte: J ${ }^{\text {Ts }}$ Halikka 'koht Rajo küla ümbruses; Rajo küla läbiv oja, mis suubub Laugasse'; $\mathrm{J}^{\mathrm{Ts}}$ Halikkõ 'külad Soikkolast Narva jõeni' jm. Sõnaalguline $h$ näitab, et tegu pole vadja, vaid pigem soome või isuri nimega. Sellega saab kõrvutada soome vallanime Halikko ja vähem tõenäoliselt linnaosanime Halinen, mille lähteks peetakse kas saksa päritolu isikunime (vrd keskaegne Halike) või genuiinset antroponüümi *Halikka, mis seostub halu-tüvega 'tahtma' (SPK).

Takaväljä ( $\mathrm{Ra}^{\mathrm{EK}}$ Takavelli jt) on praeguseks hävinud küla Lauga jõe ääres Strupovo vastas (vn Новая деревня) (TKR: 25). Peale mainitute eristati Jõgõperäl veel külaosadena J Suur čülä Suurõõ čülää õcca 'peamine osa külast' (VE III: 28; Ariste 1967: 81; tõlkes 'Suurküla ots') ja $\mathrm{Ra}^{\mathrm{ES}}$ Kolkaačülä $\sim$ Kolkkačülä 'Jõgõperä osa kiriku juures' (VE XV: 
86) < kolkka 'nurk'. Mingi, ilmselt madalam koht külas on kandnud nime $\mathrm{J}^{\mathrm{EK}}$ Alago < alago 'alang, (ranna)madalik'.

Kukkuzi külal on eristatud kaht alaosa: $\mathrm{Ku}^{\mathrm{P}}$ Alappa $(<$ ? alapi : alapaa 'allpool asuv', vrd J K alõpi : alõpaa 'madalam') ja Lauga ääres asuvat Dubrovat, mis seostub venepärase perekonnanimega.

Liivčüläl on talletatud mitme alaosa nimed, millest osa kasutatakse ühe ja sama külaotsa kohta. Nii on ka nimega Li/Lu ${ }^{\mathrm{ES}}$ Kasõ̃ õtts ehk $\mathrm{Li} / \mathrm{Lu}{ }^{\mathrm{ES}}$ Katiisaari Li Katii saari (VE XV: 53). Esimene toponüüm Kasõõ õtts on üsna problemaatiline, sest pole selge, kas see ongi üldse külaosa nimi või oleks õigem kirjutada kasõ õtts 'see siinolev ots', st külaosa, kus elas keelejuht (vrd siiski kasõ : kasõo 'kaste'). Katiisaari koosneb osistest katti : katii 'kass' + saari 'saar'. Nimetatud külaotsa vastas oleva osa nimeks on pakutud Li/Lu ${ }^{\mathrm{ES}}$ Konnaasaari $\sim \mathrm{Li}$ Konnaa saari (VE XV: 53) $<$ konna 'konn'. Liivčülä osade ülejäänud nimed on tuletatud asendist, nimelt sellest, kas küla ots on suunatud mingi teise küla või veekogu poole: $\mathrm{Lu}^{\mathrm{ES}}$ Kõhcõõ poolõõ õcca ehk Li ${ }^{\mathrm{ES}}$ Luutsaa õttsa; $\mathrm{Li}^{\mathrm{ES}}$ Laukaa õcca.

Luuditsa külal on samuti mitu otsa, mille nimed on peamiselt määratud asendiga teiste külade, kahel juhul veekogu suhtes: $\mathrm{Lu}^{\mathrm{ES}}$ Kuručülää ottsa 'Luuditsa küla osa'; Lu Kuručülää ôttsa 'Luuditsa osa, kus paiknes kool' (VE XV: 46) <*kuru 'kõrvaline paik'; Lu ${ }^{\mathrm{EK}}$ Leppäoja $\sim$ Leppoja 'Luuditsa küla idapoolne ots', Lu ${ }^{\mathrm{EK}}$ Leppäoja õttsa $<$ Leppäoja $<$ leppä 'lepp'; Lu ${ }^{\mathrm{ES}}$ Liivčülää ôttsa; Lu Luutsaa ôttsa (VE XV: 46); Lu ${ }^{\mathrm{EK}}$ Saviõjaõttsa 'Luuditsa läänepoolne ots sillast Liivtšüläni', $\mathrm{Lu}^{\mathrm{ES}}$ Savõjaa õcca 'Luuditsa küla osa sillani' < Saviõja < savi + õja 'oja'. Ingerimaa plaanitava venekeelse kohanimeleksikoni näitemärksõnade seas on Luuditsa osana nimetatud Сáвиац̧а (Nikolajev, Gerd 2015: 118). Arvestades vene keele rõhutu silbi vokaalide reduktsiooni, hääldub see üsna sarnaselt vadja nimega ja $a$-ga tähistamine pole otstarbekas. Kunagise karjateega seostub sama objekti tähistavad $\mathrm{Lu}^{\mathrm{ES}}$ Karjaa õttsa ja Lu ${ }^{\mathrm{ES}}$ Progonaa ôttsa $\sim \mathrm{Lu}^{\mathrm{EK}}$ Progonõttsa (< karja 'kari' + progona '(karja)tanum; karjatee; karjamaa'). Nime Lu ${ }^{\mathrm{EK}}$ Bräčägä ôttsa Bräăaga õttsa kandis porine maa Luuditsa küla otsas. Toponüüm lähtub üldsõnast bräčägä 'pori, muda', millega tähistatakse loodusobjekte Vaipoole teisteski külades. Lu ${ }^{\mathrm{EK}}$ Aheŕa $\sim$ Aheŕja 'Luuditsa küla osa' seostub tähenduse poolest tõenäoliselt apellatiividega aher ahõr 'aher' ja aherikko 'vilets liivane maa'. See on Jefimova teatel olnud endine lagendik, praegu aga Зеленая улица 'Roheline tänav' (TKR: 43). 
Rajo külast on registreeritud vaid $\mathrm{Ra}^{\mathrm{ES}}$ Figurovaa õtts 'külaosa, kus elas [tuntud keelejuht] Oudekki Figurova'. Üldisemalt on see nime saanud Figurovate järgi.

\section{Talunimed}

Emakeele Seltsi kohanimekogu sisaldab sadakond talunime, mis seostuvad üksnes Luuditsa ja Liivčüläga. Vadja talo on erinevalt eesti sõnast mitmetähenduslik, märkides nii talu, majapidamist kui ka maja. Konkreetseid objekte tundmata on pelgalt nime järgi võimatu kindlaks teha, mis on mis. Ainult Lu Vajennõii talo 'sõdurite puhkekodu Liivtšüläs' puhul on asi selge. Seevastu rihi (vrd ee rehi) tähistab peamiselt elumaja ja tuba, nt Grižaa rihi 'Griša maja' (Ariste 1967: 81). Mõnikord on talo ja rihi sünonüümsed: M Boranovaa talo rihi (sealsamas).

Vadja talunimed on moodustatud ainult omanike nimest. Sel puhul kasutatakse mitut moodust. Tavaliselt peegeldub talunime täiendosas perekonnanimi ja eesnimi, nt Lu Fomičaa Oke talo 'talu Liivčüläs', Lu Georgevaa Grigorii talo 'talu Luuditsas', Lu Georgeva Il'aa talo 'talu Liivčülas', Lu Georgevaa Ivanaa talo 'talu Luuditsas', Lu Georgevaa Levoo talo 'talu Liivčüläs', Lu Iitää Reiska talo (eestlane?) 'talu Liivčüläs', Lu Tsaŕkovaa Mašaa talo 'talu Luuditsas', Vittongaa Kol'aa talo 'talu Luuditsas'. Sama sage on ka kaht eesnime sisaldav talunimi, nagu Li Filatkaa Vasel'aa talo 'talu Liivčüläs', Lu ?Jagonigoo Fet'aa talo 'talu Liivčüläs', Lu Johorkaa Ivoo talo 'talu Liivčüläs', Lu Makaraa Jaakoo talo 'talu Liivčüläs', Li Petoo Johorkaa talo 'talu Liivčüläs', Lu Semonaa Paavoo talo 'talu Luuditsas'. Nimeosa Jagonigoo seondub tõenäoliselt eesnime Яков teisendiga *Jagonko : Jagongoo, mis käändub nagu genuiinne mänko : mängoo 'mäng', vrd kirjasõnast leitud kujud Ягонка ja Ягунко (Peretjatkovitš 1882: 377; Superanskaja 2010: 363). Vadja toponüümi $i$-häälik võib olla epenteetiline, et vältida kolmandale silbile omase kõrvalrõhu langemist käändetunnusele (vt Ariste 1948: 20, 22).

Suhteliselt harva koosneb talunimi vaid perekonnanimelisest täiendosast: Lu Beregudovaa talo, Lu Iljinää talo, Lu Makarovaa talo jt. Veelgi haruldasem on üksnes eesnimest koosnev talunimi: Li Gelanišaa talo, Li Levoo talo, Lu Mit'oo talo ja Lu Pamfilaa talo. Kõik selles lõigus nimetatud majapidamised asusid Liivčüläs. Gelanišaa talo puhul on oletatavasti tegu tšetšeenidel ja teistel Põhja-Kaukaasia rahvastel esineva mehenimega 
Гелан $(u) \sim$ Гилани, millele on liitunud ehk vene hellitusliide -ma, vrd Елиша < Елисей, Карниша < Корней (SSL: 137, 147, 167 jt; RF: 66, 68).

Huvipakkuvad on peamiselt Liivčülä talu- või majanimed, milles leidub eesnime täiendav, isikut mingil moel iseloomustav sõna: Lu Peremeez Pet'aa talo 'talu Luuditsas' < perem(m)eez 'peremees', Li Sepää Karpaa talo 'talu Liivčüläs'< seppä : sepää 'sepp', Li Surmaa Timoo talo 'talu Liivčüläs' < surma 'surm', Li Šlääppii Vasil'aa talo 'talu Liivčüläs' < šlääppi 'kaabu', Lu Tõrvaa Fed'aa talo 'talu Liivčüläs' < tõrva 'tõrv' ja Lu Õtsaa Jaakoo talo 'talu Liivčüläs' < õttsa 'ots'. Talunimes Li Samulii nõmaa talo 'talu Liivčüläs' esineb nõma 'oma', mis hõlmab tavalise jäänukina lisandunud eelneva nimisõna genitiivitunnuse $-n$. Omapärane on toponüüm Li Stanaanauhaa talo 'talu Liivčüläs': vdj * stanaanauha 'püksinöör'. Talukoha nimi $(\mathrm{Ku})^{\mathrm{EK}}$ Vaarivo võib ehk seonduda vene madalkeelse sõnaga варево 'kuum lake, kört' (SRJ: 73), milles $e$ hääldub $i$-lähedaselt.

\section{Rajatiste nimed}

Rajatiste nimede alla on paigutatud hoonete, kalmistute, kaevude, teede ja piiride nimed.

\subsection{Hoonenimed}

Siia rühma kuuluvad peamiselt pühakodade (kloostrite, kirikute, kabelite) nimed, mille täiendosa on külanimi ja põhisõna vastavalt kas čerikko 'kirik' või časona časovna 'kabel': J' ${ }^{\mathrm{EK}}$ Jugaa čerikko 'Joala kirik', J Jõgõperää čerikko (VE VIII: 233), Kattilaa čerikko Kattiloiščerikko (Ariste 1967: 79), Li Liivčülää časovna (VE X: 107), Li Luutsaa časovna (VE X: 107), Ra Miikkulaa čason (VE XV: 86), (L) Pihlaalaa časovna (VE I: 8) ja J ${ }^{\mathrm{EK}}$ Pühtittsä 'Pühtitsa nunnaklooster Kuremäel'. Joala kiriku all mõeldi XIX sajandi lõpul Narvas Joala linnaosas rajatud Narva Issanda Ülestõusmise õigeusukirikut. Linnaosa nimi pärineb külanime vahendusel koselt (EKNR: Joala; vrd ka vdj J ${ }^{\mathrm{EK}}(\mathrm{K})^{\mathrm{EK}} J u k a$ 'Narva juga'). Jõgõperal asunud Miikkula čason oli pühitsetud pühale Nikolausele. Peale Joala kiriku ja Pühtitsa kloostri oli vadjalastele tuntud $\mathrm{Lu}^{\mathrm{EK}}$ Juuvõli $\sim$ Juuvõlii faabrikka 'Joala vabrik'; toponüümi nime päritolu jääb praegu hämaraks. I Kapoŕoo kreeposti (VE I: 228) tähistab Kabrio kindlust, vrd vene laensõna kreeposti 'kindlus'. 


\subsection{Kalmistunimed}

Vaipoolest on talletatud kolme kalmistu (vdj kalmod) nimi: Lu ${ }^{\mathrm{ES}}$ Jõgõperää kalmod 'kalmistu Jõgõperäl kooli lähedal', Lu ${ }^{\mathrm{ES}}$ Luucaa kalmod 'kalmistu Luuditsa lähedal Tõrvajõe kaldal' ning Lu ${ }^{\mathrm{ES}}$ Švetaa sõtakalmod 'vana kalmistu Jõgõperä ja Lauga suudme vahel metsas'. Kaks esimest toponüümi pärinevad külanimest, viimane kohanimi, mis tõlkes tähendab 'Rootsi sõjakalmistu', seondub muistse surnuaiaga, mida laialt levinud uskumuse kohaselt seostati Rootsi valitsusajaga Ingerimaal XVII-XVIII sajandil ja Põhjasõjaga.

\subsection{Kaevunimed}

Kaevude (vdj kaivo) nimesid, mis pärinevad Emakeele Seltsi kogust, on teada üksnes Matist. Osa neist kutsuti omaniku järgi: Babaa Kat'aa kaivo < baaba baba 'eit; vanaema; ämmamoor'; D'äd’ää Goggaa kaivo < däädä 'onu; lell; tädimees'; Johorkaa kaivo, Petrovaa kaivo. Osa kaevusid oli tuntud asukoha põhjal: Čehsičülää kaivo < čehsičülä 'küla keskmine osa', Magazeitüvenää kaivo < magaze magazei 'magasiait' + tüvenä 'juures', Orkokaivo < orko 'org; mäeveer'.

\subsection{Teenimed}

Osa teede (vdj tee) nimedes väljendub sihtkoht (küla, heinamaa jm): $\mathrm{Li}^{\mathrm{ES}} \mathrm{Lu}^{\mathrm{ES}}$ Jõgõperää tee 'tee Liivčüläst Jõgõperäle', $\mathrm{Lu}^{\mathrm{ES}}$ Kazikooniitüü tee 'tee Luuditsast Kaasikuniidule', $\mathrm{M}^{\mathrm{ES}}$ Korvaizii tee '[tõenäoliselt tee Korovaisi külla]', M ${ }^{\mathrm{ES}}$ Kõrvõttulaa tee 'tee Matist läbi Kõrvõttula Süväjärvele', Li Laugastee (VE XV: 71), Li/Lu ${ }^{\mathrm{ES}}$ Laukastee 'tee Lauga külla; tee Liivčüläst Jõgõperäle = Maatee', $\mathrm{Lu}^{\mathrm{ES}}$ Rizümäee tee 'tee Luuditsast Rüsümäele', Li Rüsümäe tee (VE XV: 71), Lu ${ }^{\mathrm{ES}}$ Sarainiitüü tee 'tee Sarainiitüle', $\mathrm{M}^{\mathrm{ES}}$ Savvokkolaa tee. $\mathrm{Ka} \mathrm{Lu}^{\mathrm{ES}}$ Mõizaatee 'tee Liivtšüläst Rüsümäele' näitab sihtkohta - Rüsümäe mõisa. Erandina märgib $\mathrm{Ku}^{\mathrm{P}}$ Revoo tee mitte sihtpunkti, vaid teed Repo soos (repo : revoo 'rebane').

Teine osa teenimesid on ühenduses nende omadustega, nt teekattega, iseloomulike puudega tee ääres: $\mathrm{Ku}^{\mathrm{P}}$ Kivitee 'mingi tee nimi', $\mathrm{Ku}^{\mathrm{P}}$ Lomutee 'mingi tee' < lomu 'rämps; tuulemurd', $\mathrm{Li} / \mathrm{Lu}^{\mathrm{ES}}$ Maatee 'tee Liivčüläst Jõgõperäle' < maatee 'maantee; külavahetee' (vt TKR: 43), Lu ${ }^{\mathrm{ES}}$ Metts $\ddot{a}$ tee 'tee Jõgõperält Kõhtsõsse' < mettsä 'mets', Lu ${ }^{\mathrm{ES}}$ Petäzikoo tee 'vana 
tee Kõhtšizõõ külla' < petäzikko 'pedastik, männik', Lu ${ }^{\mathrm{ES}}$ Põlloo tee 'põlluvahetee Saarepõllul' < põlto : põlloo 'põld', KuP Uustee 'Kõhčiselt Süväkaivoni kulgev tee' < uusi 'uus', $\mathrm{Li}^{\mathrm{ES}}$ Välitee 'tee Jõgõperält läbi metsa Kõhtsesse'< väli 'vahe (mitmes tähenduses)'.

\subsection{Piirinimed}

Emakeele Seltsi kogus leidub kolme piiri (vdj raja) nimi, mis on talletatud Rajo külast: Baikkovaa raja, Korovinaa raja ja Kunikvalla raja. Võimalik, et esimene toponüüm kajastab piiri Narvuzi lähedal asunud Haliki mõisaga, mille omanikeks olid Baikovid (DUS: 198-200). Ka teine kohanimi seostub mõisaga (vt ptk 4). Kolmas nimi tähistab Jõgõperä Kunik- ja Herrvalla vahelist raja (vt ptk 6).

\section{Kokkuvõte}

Vadjalastel oli rohkesti nimesid eri kohtade tähistamiseks. Ingerimaa linnanimed tulenevad vene ametliku nime esiosast (Jaama, Petteri) või vene kõnekeelsest nimekujust (Rambov), samuti on need saadud vene nime tõlkimisel (Ivoolidna) või põlisküla nime järgi (Kabrio). Eesti linnade nimed esinevad kas peaaegu samal kujul kui eestlastel (v.a Pakari 'Narva-Jõesuu') või tsaariaegse vene nimena (Fellin 'Viljandi', Reeveli 'Tallinn' jt). Mõisanimed on tuletatud kas asukoha (külade) (nt Rüsümäe mõiza) või omaniku järgi (Piippinaa mõiza) või on võetud omaks vene nimi (Korovinaa mõiza).

Vadjalastega asustatud külade nimetamisel on olnud aluseks 1) muistsed isikunimed (*Assila $\sim *$ Assizi, Kukkuzi jt), 2) rahvanimetused (Tiutitsõ, *Vad'dd'aa[čülä]), 3) kristlikud isikunimed (Iivanaisi jt), 4) ümbruskonna omadused (*Karakkola < 'kuivanud oksad', Kazikko < 'kaasik' jt), 5) küla asend (Jõgõperä 'Jõepera, Jõetaguse', Mäč $<$ 'mägi' jt) ning 6) muud iseärasused (Kerstova, Koslova 'Gostilovo' jt). Mitme külanime (Kikeritsõ, Pummala jt) päritolu pole seni õnnestunud selgitada. Selgitatud on Vadjamaa muude rahvastega asustatud külade nimede (Muuka, Palokka, Saira) päritolu. Külaosade nimesid käsitletatakse külade kaupa; teistest rohkem on neid Jõgõperäl, Liivčüläl ja Luuditsal. Talunimed (Fomičaa Oke talo, Sepää Karpaa talo jt) on moodustatud mitmel viisil eranditult omaniku nimest. Rajatiste nimesid on kogutud üsna vähe. 


\section{Lühendid}

${ }^{\mathrm{EK}}=$ Eesti Keele Instituudi vadja kohanimekogu; ${ }^{\mathrm{ES}}=$ Emakeele Seltsi vadja kohanimekogu; I = Ičäpäivä; J = Jõgõperä; Ja = Jarvikoiščülä; $\mathrm{K}=$ Kattila; $\mathrm{K}=$ Kettunen 1986; Ku = Kukkuzi; Kõ = Kõrvõttula; $\mathrm{L}=$ Lempola; $\mathrm{Li}=$ Liivčülä; $\mathrm{Lu}=$ Luuditsa; $\mathrm{M}=$ Mati; $\mathrm{Ma}=\mathrm{Mahu} ;{ }^{\mathrm{N}}=$ Nirvi 1971; $\mathrm{P}=$ Pummala; ${ }^{\mathrm{P}}=$ Posti 1980; Po = Pontizõõ; $\mathrm{R}=$ Rudja; $\mathrm{Ra}=$ Rajo; $\mathrm{S}=$ Savvokkala $;{ }^{\mathrm{T}}=$ Talve 1981; Ts = Tsvetkov 1995; U = Undova; V = Velikkä; Vai = Vaipooli; X = külanimi teadmata

\section{Kirjandus ja veebiallikad}

$\mathbf{A H}=$ Asutusnimihakemisto. Kotimaisten kielten keskus. http://kaino.kotus.fi/ asutusnimihakemisto/index.php? $\mathrm{a}=$ listaus\&hakunimi $=(15.01 .2020)$.

Ariste, Paul 1936. Svenska lånorfrån svensktiden i estniska språket. - Svio-Estonica. Akadeemilise Rootsi-Eesti Seltsi aastaraamat. Tartu: Akadeemiline Rootsi-Eesti Selts, 185-200.

Ariste, Paul 1948. Vadja keele grammatika. (= Nõukogude soome-ugri teadused 9.) Tartu: Teaduslik Kirjandus.

Ariste, Paul 1964. Baabino ehk Jarvigoiščülä. (Ühest vadja külanimest). - Emakeele Seltsi aastaraamat 1964. Tallinn, 167-172.

Ariste, Paul 1965a. Vadja kohanimedes. - Slaavi-läänemeresoome suhete ajaloost. Toim. Harri Moora, Lembit Jaanits. Tallinn: Eesti Raamat, 91-106.

Ariste, Paul 1965b. Über wotische Ortsnamen. - Zweiter Internationaler Finnougristenkongress, Helsinki, 23.-28.08.1965. Referate der Vorträge und Mitteilungen. [Helsinki,] 4-5.

Ariste, Paul 1967. Über wotische Ortsnamen. - Советское финно-угроведение 2, 77-84.

Ariste, Paul 1968. Über wotische Ortsnamen. - Congressus Secundus Internationalis Fenno-Ugristarum Helsingiae habitus 23-28. VIII 1965. Helsinki. (=1. Acta linguistica.) Helsinki: Societas Fenno-Ugrica, 24-30.

Baklund, Astrid 1959. Personal names in medieval Novgorod 1. Common names. (= Acta Universitatis Stockholmiensis: Études de philologie slave 9.) Stockholm: Almqvist \& Wiksell.

DEO $=$ Niels Åge Nielsen 1976. Dansk etymologisk ordbog. Ordenes historie. 3., reviderede udgave med et tillæg. Copenhagen: Gyldendal.

Dmitrijev 2007 = А. В. Дмитриев 2007. Водская топонимика в историко-культурном аспекте. - Псковский регионологический журнал 4, 110-118.

Dmitrijev $2016=$ А. В. Дмитриев 2016. Топонимия Ивангородского лена 1580 -х годов. Материал для историко-топонимического словаря Ингерманландии. - Linguistica Uralica 4, 247-265. 
Dmitrijev $2018=$ А. В. Дмитриев 2018. Ватландия и ватландцы (ваты) в ливонских источниках XIV-XV вв. - Севернорусские говоры 17. Ответственный редактор Е. В. Пурицкая. Санкт-Петербург: ИЛИ PAH, 271-293.

DUS $=$ Н. В. Мурашова, Л. П. Мыслина 2003. Дворянские усадьбы СанктПетербургской губернии. Кингисеппский район. Санкт-Петербург: Информационный центр «Выбор».

EDW $=$ Ferdinand Johann Wiedemann 1973. Estnisch-deutsches Wörterbuch. Eesti-saksa sõnaraamat. 4., muutmata trükk teisest, Jakob Hurda redigeeritud väljaandest. Tallinn: Valgus.

EES = Eesti etümoloogiasõnaraamat, 2012. Koost. ja toim. Iris Metsmägi, Meeli Sedrik, Sven-Erik Soosaar. Peatoim. Iris Metsmägi. Eesti Keele Instituut. Tallinn: Eesti Keele Sihtasutus. http://www.eki.ee/dict/ety/.

EKNR = Marja Kallasmaa, Evar Saar, Peeter Päll, Marje Joalaid, Arvis Kiristaja, Enn Ernits, Mariko Faster, Fred Puss, Tiina Laansalu, Marit Alas, Valdek Pall, Marianne Blomqvist, Marge Kuslap, Anželika Šteingolde, Karl Pajusalu, Urmas Sutrop 2016. Eesti kohanimeraamat. Toim. Peeter Päll, Marja Kallasmaa. Eesti Keele Instituut. Tallinn: EKSA. https://www.eki. ee/dict/knr/ (02.03.2020).

EMK = Karl Pajusalu, Tiit Hennoste, Ellen Niit, Peeter Päll, Jüri Viikberg 2020. Eesti murded ja kohanimed. 3., kohendatud ja täiendatud trükk. Tartu.

EMS IV = Eesti murrete sõnaraamat IV I $_{17}$. kõhvits - kähür, 2005. Toim. Evi Juhkam, Mari Kendla, Piret Norvik, Jüri Viikberg. Tallinn: Eesti Teaduste Akadeemia Eesti Keele Instituut.

EO $=$ Lauri Kettunen 1955. Etymologische Untersuchung über estnische Ortsnamen. (= Suomalaisen Tiedeakatemian toimituksia B 90.. ) Helsinki.

Ernits, Enn 2017. Sõna haaval emakeelest tehiskeelteni. (= Eesti Teaduste Akadeemia Emakeele Seltsi toimetised 75.) Tallinn: Emakeele Selts.

ESR I-II = Макс Фасмер 1986. Этимологический словарь русского языка 1-2. Издание 2-е, стереотипное. Москва: Прогресс.

ETK $=$ Peter v. Köppen 1867. Erklärender Text zu der ethnographischen Karte St. Petersburger Gouvernements. St.-Petersburg.

GCI $=$ General Charta Öfver Provincien Ingermanneland, 1704. [Koost. Andres Andersin 1678. aasta ja hilisemate mõõtmiste põhjal.] http://www. aroundspb.ru/karty/152/sg_1678_beling.html (12.01.2020).

Grünthal, Riho 1997. Livvistä liiviin. Itämerensuomalaiset etnonyymit. (= Castrenianumin toimitteita 51.) Helsinki.

GTI = Географический чертеж над Ижорскою землею со своими городами Адриана Шонбека, 1705. http://www.aroundspb.ru/maps/shonback/ shonback_07.gif (12.01.2010). 
IEO = Ивангород и его окрестности. https://www.stena.ee/blog/oldnarva/ ivangorod-i-ego-okrestnosti-naibolee-polnoe-opisanie-dlya-turistov-iinteresuyuschihsy (12.01.2020).

JI = Jordeböcker öfver Ingermanland. Писцовые книги Ижорской земли 1. Годы 1618-1623, 1859. Санктпетербург.

Kartavenko 2011 = В. С. Картавенко 2011. Календарные имена в составе топонимов. - Филологические науки 3, 311-320.

Kepsu, Saulo 1990. Inkereen nimistön ja asutuksen vaiheita. - Inkerin teillä. (Kalevalaseuran vuosikirja 69/70.), Helsinki: Suomalaisen Kirjallisuuden Seura, 149-166.

Kislovskoi $1974=$ С. В. Кисловской 1974. Знаете ли Вы? Словарь географических названий Ленинградской области. Ленинград: Лениздат.

Kettunen, Lauri 1915. Vatjan kielen äännehistoria. Helsinki: Suomalaisen Kirjallisuuden Seura (Eripainos aikakauskirjasta „Suomi“).

Kettunen, Lauri 1986. Vatjan kielen Mahun murteensanasto. Toim. Jarmo Elomaa, Eino Koponen, Leena Silfverberg. (= Castrenianumin toimitteita, 27.) Helsinki.

KK = Saulo Kepsu 2018. Kannaksen kylät. (= Kotimaisten kielten keskuksen verkkojulkaisuja 54.) Helsinki: Kotimaisten kielten keskus. http://scripta. kotus.fi/www/verkkojulkaisut/julk54/Kannaksen_kylat.pdf(02.03.2020).

Koivulehto, Jorma 1997. Were the Baltic Finns "clubmen"? - You name it. Perspectives on onomastic research. Ed. by Ritva Liisa Pitkänen, Kaija Mallat. (= Studia Fennica linguistica 7.) Helsinki: Finnish Literary Society, 151-169.

Laanest 1966 = Арво Лаанест 1966. Ижорские диалекты: Лингвогеографиеское исследование. Таллин: Академия наук Эстонской ССР.

Mikkola, J. J. 1932. Inkerinmaan kreikanuskoisten käännytyksestä vuosina 1683-1700. - Historiallinen Arkisto 39, 1-46.

MSD I = И. И. Срезневский Материалы для словаря древнерусского языка по письменным памятникам 1. А-К, 1893. Санктпетербург.

Mullonen 2002 = И. И. Муллонен 2002. Топонимия Присвирья. Проблемы этноязыкового контактирования. Петрозаводск.

Neroznak 1983 = В. П. Нерознак 1983. Названия древнерусских городов. Москва: Наука.

Nikolajev, Gerd 2015 = И. С. Николаев, А. С. Герд 2015. Словарь топонимии и микротопонимии Ингерманландии. Северорусские говоры. Межвузовский сборник 14. Ответственные редакторы А. С. Герд, Е. В. Пурицкая. Санкт-Петербург: Нестор-История, 112-119.

Nikonov 1966 = В. А. Никонов 1966. Краткий топонимический словарь. Москва: Мысль. 
Nirvi, R. E. 1971. Inkeroismurteiden sanakirja. (= Lexica Societatis FennoUgricae 18.) Helsinki: Suomalais-Ugrilainen Seura.

NPI = Народные песни Ингерманландии, 1974. Издание подготовили Эйно Киуру, Тертту Коски, Элина Кюльмасу. Ленинград: Наука.

NPK = Новгородские писцовые книги, изданные Археографическою комиссиею 3. Переписная оброчная книга Вотской пятины 1500 года. Первая половина, 1868. Санктпетербург.

OBG = Карта бывших губерний Ингерманландии Ивангорода, Яма, Копорья, Нэтеборга составленная [...] 1827 года под присмотром генералмайора Шуберта [...] показывающая разделение и состояние оного края в 1676 г. http://www.aroundspb.ru/maps/ingermanland/ 1676/1676 inger3.jpg (12.01.2020).

$\mathbf{O P G}=$ Описание Санкт-Петербургской губернии по уездам и станам, 1838 . Санкт-Петербург.

ОРК = А. М. Гневушин 1908. Отрывок писцовой книги Вотской пятины второй половины 1504-1505 г. Киев.

$\mathbf{O P P}=$ Описание пригородов Петербурга. http:/gopiter.ru/piter/culturerest/ prigorod/lomonosov/ (16.12.2019).

Peretjatkovitš $\mathbf{1 8 8 2}=$ Г. Перетяткович 1882. Поволжье в XVII и начале XVIII века. (Очерки из истории колонизации края.) Одесса.

Posti, Lauri 1980. Vatjan kielen Kukkosin murteen sanakirja. Painokuntoon toimittanut Seppo Suhonen Lauri Postin avustamana. (= Lexica Societatis Fenno-Ugricae 19.) Helsinki: Suomalais-Ugrilainen Seura.

$\mathbf{R F}=$ Б. О. Унбегаун 1989. Русские фамилии. Москва: Прогресс.

Saar, Eva 2016. Vene õigeusu eesnimed vadja, isuri ja seto keeles. - Emakeele Seltsi aastaraamat 61 (2015). Peatoim. Mati Erelt. Tallinn: Teaduste Akadeemia Kirjastus, 167-186. http://dx.doi.org/10.3176/esa61.08.

$\mathbf{S D L}=$ Н. М. Тупиков 1903. Словарь древнерусских личных собственных имен. С.-Петербург.

SPK = Suomalainen paikannimikirja, 2007. Peatoim. Sirkka Paikkala. (= Kotimaisten kielten tutkimuskeskuksen julkaisuja 146.) Karttakeskus, Kotimaisten kielten tutkimuskeskus.

SRG IV = Словарь русских говоров Карелии и сопредельных областей 4 , 1999. Главный редактор А. С. Герд. Санкт-Петербург: Издательство С.-Петербургского университета.

$\mathbf{S R J}=$ С. И. Ожегов 1990. Словарь русского языка. Москва: Русский язык.

SRN I-XCVI = Словарь русских народных говоров 1-46, 1965-2013. Москва, Ленинград, Санкт-Петербург: Наука.

SRS II = Lönnrot, Elias 1958 [1826]. Suomalais-ruotsalainen sanakirja 2. 3., manul-menetelmällä jäljennetty painos. Porvoo, Helsinki: Werner Söderström. 
SSA I-III = Suomen sanojen alkuperä. Etymologinen sanakirja, 1992-2000.

(= Suomalaisen Kirjallisuuden Seuran toimituksia 556. Kotimaisten kielten tutkimuskeskuksen julkaisuja 62.) Helsinki.

SSL = Сводный словарь личных имен народов Северного Кавказа, 2012. Ответственный редактор: Р. Ю. Намитокова. Москва: Флинта, Наука. SSN = Suuri suomalainen nimikirja, [1985]. Helsinki: Suuri suomalainen kirjakerho.

Stoebke, Detlef-Eckhard 1964. Die alten ostseefinnischen Personennamen im Rahmen eines urfinnischen Namensystems. Hamburg: Leibnitz-Verlag.

Superanskaja $2010=$ А. В. Суперанская 2010. Словарь народных форм русских имен. Москва: Книжный дом «Либрок ОМ».

Talve, Ilmar 1981. Vatjalaista kansankulttuuria. (= Suomalais-Ugrilaisen Seuran toimituksia 179.) Helsinki: Suomalais-Ugrilainen Seura.

$\mathbf{T K P}=$ Топографическая карта Санкт-Петербургской губернии, состаленная под руководством Ф. Ф. Шуберта, 1834. http://www.etomesto.ru/mappeterburg_5verst/\#n (13.01.2020).

TKR $=$ Топонимика Кингисеппского района. Электронное дополняемое издание, 2009. Кингисепп. https://docplayer.ru/26608378-Toponimikakingiseppskogo-rayona-elektronnoe-dopolnyaemoe-izdanie-sost-v-vdemina.html (11.01.2020).

Tsvetkov, Dmitri 1995. Vatjan kielen Joenperän murteen sanasto. Toimittanut, käänteissanaston ja hakemiston laatinut Johanna Laakso. (= Lexica Societatis Fenno-Ugricae 25.) Helsinki: Suomalais-Ugrilainen Seura, Kotimaisten kielten tutkimuskeskus.

Ust-Luga = Усть-Луга. https://ru.wikipedia.org/wiki/Усть-Луга (02.01.2020). Vagner 2014 = Б. Б. Вагнер 2014. Карта рассказывает. Природа и история, имена и судьбы в географических названиях Подмосковья. Топонимико-краеведческий словарь. Москва: Книга по требованию.

VKS = Vadja keele sõnaraamat, 2013. 2., täiendatud ja parandatud trükk. Toim. Silja Grünberg. Tallinn: Eesti Keele Sihtasutus.

\section{Käsikirjalised allikad}

Eesti Keele Instituudi kohanimekartoteek. Eesti Keele Instituudi vadja kogu. http://heli.eki.ee/roheline/index.php?khk=vdj\&om=eki1 (12.01.2020).

Eesti Keele Instituudi kohanimekartoteek. Emakeele Seltsi kogu. http://heli.eki. ee/roheline/index.php?khk=vdj\&om=es1 (12.01.2020).

VE I-XVIII = Ariste, Paul. Vadja etnoloogiat 1-18. Eesti Kirjandusmuuseum. 


\title{
The Votian habitation names
}

\author{
ENN ERNITS
}

The paper deals with Votic habitation names in a broader sense than usual, encompassing, apart from the names of settlements and their subdivisions, all objects associated with the population and settlement from farms to countries. The main attention is paid to the names of the villages inhabited by the Votians as well as the names of other Voteland villages known to them. Village names are grouped by semantic groups in alphabetical order. Russian names of Votian and neighboring villages and their relations with Votian names have also been studied. Each name is accompanied by interesting historical names dating from the 1500s and subdialectal dates collected in the 20th century. Old etymologies are supplemented, and new ones added.

The Votians had many names to denote different places. Ingrian city names are derived from the official Russian names (Jaama, Petteri), Russian spoken names (Rambov), Russian calques (Ivoolidna) or by the name of a native village (Kabrio). The names of Estonian cities appear in almost the same form as in the Estonian use (except Pakari 'Narva-Jõesuu') or in form of the Russian names of the Tsarist era (Fellin 'Viljandi', Reeveli 'Tallinn', etc.). The manor names are derived either by location (villages) (e.g. Rüsümäe mõiza), owner (Piippinaa mõiza) or Russian name (Korovinaa mõiza).

The names of villages inhabited by Votians were based on 1) ancient personal names (*Assila $\sim *$ Assizi, Kukkuzi, etc.), 2) ethnic names (Tiutitsy, *Vad'dd'aa [čülä]), 3) Christian personal names (Iivanaisi, etc.), 4) neighborhood features (* Karakkola < 'place of dried branches', Kazikko < 'birch wood, birch grove', etc.), 5) village position (Jõgõperä < 'the nearest village to the river mouth', Mäči< 'mountain') and 6) other features (Kerstova, Koslova 'Gostilovo' etc.). The origin of several village names (Kikeritsõ, Pummala, etc.) has not yet been explained. The origin of the village names (Muuka, Palokka, Saira) established with other nations of Votland is explained. The names of the parts of the village are treated by villages; more of them they are in Jõgõperä, Liivčülä and Luuditsa. Farm names such as Fomičaa Oke talo, Sepää Karpaa talo, etc.) are formed in many ways exclusively from the name of the owner. Quite a few names of sacral buildings, cemeteries, wells, and roads have been collected. 
Keywords: etymology, habitation names, toponyms, Votic, Izhorian, Russian, Voteland, Ingria, Estonia

\section{Enn Ernits}

enn.ernits@emu.ee 